\title{
8. MAGNETOSTRATIGRAPHY OF MIOCENE AND PLEISTOCENE SEDIMENTS ON THE NEW JERSEY SLOPE ${ }^{1}$
}

\author{
Mickey C. Van Fossen ${ }^{2}$ and Michael Urbat ${ }^{3}$
}

\begin{abstract}
Magnetostratigraphic data are presented for lower, middle, and upper Miocene and middle-upper Pleistocene terrigenous sections recovered during Ocean Drilling Program Leg 150 (New Jersey Margin). The study is focused on Site 903 (upper slope) and Site 904 (lower slope). Large-volume $\left(42 \mathrm{~cm}^{3}\right)$, quarter core discrete samples are used as a means of enhancing the practical sensitivity to measurement of very weakly magnetized sediments. Magnetostratigraphic correlations to the geomagnetic polarity time scale (GPTS) are made within the framework set forth by the biostratigraphic information and $\mathrm{Sr}$ age data. At Site 903, the magnetostratigraphy of Pleistocene, Pliocene, and Miocene sections to a depth of 800 mbsf is supported by diatoms, planktonic foraminifers, and dinoflagellate cysts. At Site 904, magnetostratigraphic correlation of Pleistocene and Miocene sections ( $0-400 \mathrm{mbs})$ is supported by planktonic foraminifers and $\mathrm{Sr}$ isotope data. A middle-upper Miocene sedimentary section at Site 903 and at Site 904 bounded by common disconformities (and identified with seafloor seismic reflectors) fails to correlate magnetostratigraphically, suggesting the sedimentary sequence is younger downslope.
\end{abstract}

\section{INTRODUCTION}

The overall goal of Ocean Drilling Program Leg 150 was to identify and date Oligocene through Holocene unconformities in sediments recovered beneath the continental slope off the New Jersey coast (Fig. 1). The scientific party sought to combine all available methods of dating sediments (biostratigraphy, Sr-isotope stratigraphy, magnetostratigraphy) to estimate the age ranges of distinct packages of sediments (sequences) bounded by major breaks in lithologic character (sequence boundaries). By estimating the "missing time" on slope sediments and correlating these sequence boundaries to seismic reflectors beneath the shelf and slope (Christie-Blick et al., 1990; Greenlee et al., 1992), we sought to describe the sedimentary record of sea level change on the upper slope. This constitutes the first step in a longer term study to understand the development of a classic passive margin under the influence of changes in global sea level.

Magnetostratigraphy has the potential to improve greatly the dating precision obtainable through biostratigraphy (planktonic foraminifers, nannofossils, diatoms, and dinocysts) once the general biozonations of sedimentary sequences are established. Should fossil preservation become poor or absent in any particular sequence, magnetostratigraphy has the further potential to provide an age estimate based on a pattern fit to the geomagnetic polarity time scale (GPTS). Ultimately, the success of magnetostratigraphy will depend on the thickness of sequences and rates of sedimentation, as well as the predicted frequency of geomagnetic field reversal based on the GPTS.

Thorough demagnetization and progressive removal of any secondary magnetic contaminations form the groundwork of all paleomagnetic studies and are designed to resolve the most stable magnetization. In magnetostratigraphy, once a stable magnetization has been resolved, it is then a matter of merging the pattern of polarity re-

'Mountain, G.S., Miller, K.G., Blum, P., Poag, C.W., and Twichell, D.C. (Eds.), 1996. Proc. ODP, Sci. Results, 150: College Station, TX (Ocean Drilling Program). ${ }^{2}$ Department of Geological Sciences, Rutgers University, Piscataway, NJ 08855 U.S.A. mick@Ideo.columbia.edu

${ }^{3}$ Geologisches Institut, Universistät zu Köln, Zülpicher Strasse 49A, 50674 Köln, Federal Republic of Germany. versals with all of the available age data from the sediments and gauging how sensibly the record of magnetobiostratigraphy compares to the GPTS. As outlined below, the sediments recovered during Leg 150 are very weakly magnetized. Using the pass-through system aboard the JOIDES Resolution, we found it difficult to identify a

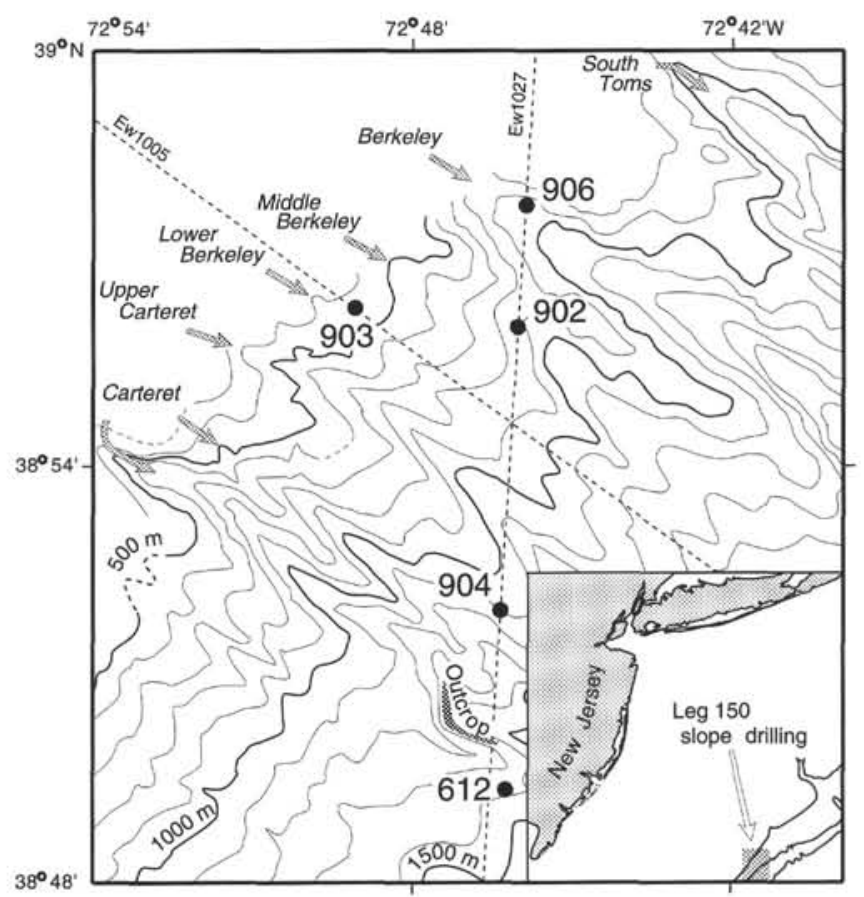

Figure 1. SeaBeam bathymetric location map of the middle continental slope (500-1500 m water depth) drilled during Leg 150, showing ODP Sites 902 , 903,904 , and 906, and DSDP Site 612. SeaBeam data were collected by Atlantis II 120 and 124 and processed by W.B.F. Ryan and D. Twichell (unpubl. data, 1989; map after Mountain, Miller, Blum, et al., 1994). Ew1005 and Ew1027 are Ewing multichannel seismic profiles shown in Mountain, Miller, Blum, et al. (1994). 
primary magnetization and establish a pattern of magnetic field reversals in the pre-Pleistocene sections recovered. There were, however, a few limited intervals where a magnetostratigraphy could be identified, but these correlations were entirely governed by the shipboard biostratigraphy. Nowhere could we establish a continuous succession of polarity reversals for an independent, magnetostratigraphic assessment of age. During Leg 150 it became increasingly clear that we would have to attempt to extract the magnetostratigraphic record in the sediments through onshore laboratory methods using large-volume, quarter-core samples.

In this paper, following a description of methods, the shipboard paleomagnetic data are summarized. The land-based studies at Sites 903 and 904 are then presented and discussed in detail. We use the Berggren et al. (1985) GPTS to maintain consistency with shipboard and other shore-based studies, but adopt the naming convention of Cande and Kent (1992). This approach is required because the revised geological time scale based on the GPTS of Cande and Kent (1992) was not available at the time of this study. All Leg 150 studies will need to be recalibrated to the revised geological time scale. Where identified, reversal boundaries are referenced to onsets or terminations of magnetochrons using the suffixes "O" or " $\mathrm{T}$," respectively.

\section{METHODS}

In the pass-through system, the relatively large volume of material within the measurement region of the cryogenic magnetometer ( $\sim 280 \mathrm{~cm}^{3}$ for an ODP split core) enables the measurement of generally weak magnetizations. Materials magnetized at an intensity above roughly $0.1 \mathrm{~mA} / \mathrm{m}$ will provide a signal in excess of the magnetometer's noise level and inherent magnetization of the core liner. Unfortunately, rotary and extended core barrel (XCB) coring often disturbed thick intervals of recovered core, forming "biscuit-like" structures surrounded by what was often a relatively strongly magnetized slurry of core cuttings. Such biscuiting at lengths close to that of the magnetometer's response function $(\sim 20 \mathrm{~cm})$ limited our ability to extract any detailed magnetostratigraphic information from the passthrough data. In addition, the upper limit of alternating field (AF) demagnetization available in the pass-through system during Leg 150 was only $15 \mathrm{mT}$ and commonly less than or equal to $10 \mathrm{mT}$. From the interpretable pass-through data we were able to detect a steep secondary magnetization in the sediments (probably a core barrel effect) and determined that the primary magnetization could only be revealed through progressive demagnetization beyond the levels available during the leg.

The potential solution to these problems aboard ship was to subsample the working halves of cores using $6-\mathrm{cm}^{3}$ plastic boxes. Through subsampling, one is able to elude the drilling slurry and more thoroughly remove any secondary magnetizations using the single-specimen AF demagnetizer. Unfortunately, although demagnetization to $100 \mathrm{mT}$ was attainable using this method, the much smaller volume of material in the subsample greatly reduced the magnetization signal to near the noise level of the magnetometer (effectively requiring the material to be magnetized at roughly $1 \mathrm{~mA} / \mathrm{m}$ or greater). Thus, most of the sediments recovered during Leg 150 were either too weakly magnetized and/or too disturbed to generate useful pass-through data, although, in conjunction with the shipboard biostratigraphy, we were able to suggest polarity zonations in relatively strongly magnetized intervals (principally, in middle through upper Pleistocene clays and portions of middle and upper Miocene silty clays).

\section{Large-Volume Sampling Method}

To overcome these problems, we decided to subsample the cores using the standard $50-\mathrm{cm}^{3}$ quarter-core sampling device. These quar- ter-core samples allow us to reap certain benefits of the pass-through method (i.e., larger volume of material) and the $6-\mathrm{cm}^{3}$ subsampling method (i.e., higher quality material and potential to more thoroughly demagnetize). This approach has been successful in magnetostratigraphic studies of weakly magnetized Coastal Plain sediments in New Jersey (Miller et al., 1990), Alabama (Miller et al., 1993), and current studies of Eocene-Miocene sediments of the Island Beach and Atlantic City cores from the New Jersey onshore drilling project (Ocean Drilling Program Leg 150X). The actual volume of an ODP quarter core sample is $42 \mathrm{~cm}^{3}$ and thus, assuming a homogenous magnetization, the signal at the magnetometer is increased sevenfold over the standard ODP paleomagnetic sample. We estimate that with this greater volume of material and elimination of the core liner through subsampling, one can achieve an effective sensitivity of 0.02 $\mathrm{mA} / \mathrm{m}$. In addition, a larger sample may be able to poll a more representative population of magnetic grains, which is particularly useful in nearshore environments where the high energy of deposition can result in a heterogeneous and inefficient magnetization in sediments. The only real disadvantage of this method is that we lose the relative ease and continuity of data acquisition available in the pass-through system.

The paleomagnetism laboratory at the Lamont-Doherty Earth Observatory is equipped with a large-volume AF demagnetization coil in which samples up to $\sim 300 \mathrm{~cm}^{3}$ can be demagnetized to $50 \mathrm{mT}$. This enabled us to decompose the natural remanent magnetization of each sample to reveal the more stable magnetization. All measurements of magnetic remanence were made on a $2 \mathrm{G}$ cryogenic magnetometer, similar to the model aboard the JOIDES Resolution. Two largeaccess thermal demagnetizers with internal fields of $<10 \mathrm{nT}$ were also available for thermal decomposition. Measurement and demagnetization experiments were conducted within a shielded room with a nominal internal field of $200 \mathrm{nT}$.

In each sample the most stable magnetization vector was identified through analysis of demagnetization data in orthographic projection. The method of least-squares analysis (Kirschvink, 1980) was applied to the demagnetization trajectories to calculate least-squares best-fitting vectors, with inclination forming the basis of polarity determination. An estimate of the percentage of total variance in the selected data and an intensity of the best-fit magnetization vector are also provided by the least-squares analysis. These parameters are used in the evaluation of data reliability.

\section{RESULTS}

With the exception of Site 905 (which bore no interpretable magnetization), the Leg 150 sites contained a partial record of the Brunhes Chron in the upper $\sim 100 \mathrm{~m}$ of sediment (or $\sim 330 \mathrm{~m}$ at upper slope Site 903) above the first major disconformity. Aboard ship we were able to make preliminary correlations to the GPTS of upper, middle, and lower Miocene sections at Sites 902, 903, 904, and 906. We have focused our land-based paleomagnetic work on Sites 903 and 904, considering the amount of time budgeted for the study, and in keeping with the primary goals of Leg 150 and the shipboard scientific party. Sites 903 and 904 might be regarded as "representative" Leg 150 sites, because they sampled Miocene, upper Oligocene, and upper Eocene sections on the upper slope with relatively high sedimentation rates (Site 903), and on the lower slope with relatively low sedimentation rates (Site 904; Fig. 1). Preliminary indications from the shipboard work suggested that both of these sites contained a zone of Miocene sediments of similar age with a relatively strong magnetization worthy of further investigation.

\section{Site 903}

Site 903 is located at $38^{\circ} 56^{\prime} \mathrm{N}, 72^{\circ} 49^{\prime} \mathrm{W}$ on the upper slope in 444 $\mathrm{m}$ of water (Fig. 1). A section of nearly $1150 \mathrm{~m}$ of middle and upper 
Eocene pelagic carbonate, upper Oligocene silty clay, Miocene glauconitic silty clay or sand, middle Pliocene sand, and middle Pleistocene to Holocene silty clay was recovered in four holes.

As in all other pre-Pleistocene cores from Leg 150, the passthrough measurements yielded erratic results at best. At Site 903, we abandoned the pass-through system below 500 mbsf because at the upper limit of AF demagnetization ( $15 \mathrm{mT}$ ), the sediments either became too weak to measure or, as we suspected, secondary core-barrel magnetizations were not being fully removed. In the isolated intervals where magnetization intensities did increase, $\mathrm{AF}$ demagnetization of standard discrete samples to $70 \mathrm{mT}$ demonstrated normal- and reversed-polarity magnetizations distinct from the secondary overprinting. Perhaps the most reliable pass-through data came from the upper 400-m section of Hole 903A (Fig. 2). Demagnetized intensities varied from $50 \mathrm{~mA} / \mathrm{m}$ to less than $0.1 \mathrm{~mA} / \mathrm{m}$ and while somewhat scattered, inclinations were consistently normal over this interval. The more thoroughly demagnetized $6-\mathrm{cm}^{3}$ cubes analyzed aboard ship tended to average the overall scatter in inclination seen in the pass-through data. The section from the seafloor to $332.56 \mathrm{mbsf}$ was entirely normal in polarity, which is not unexpected given the shipboard age determinations of middle and late Pleistocene over this interval (Mountain, Miller, Blum, et al., 1994). There is a thin interval of reversed magnetization between 340.07 to $348.0 \mathrm{mbsf}$, confirmed by more complete demagnetization of two discrete $6-\mathrm{cm}^{3}$ samples. Aside from these data, we judged the bulk of the magnetizations measured at Site 903 as generally very weak and scattered and thus could only make tentative assignments of polarity aboard ship.

The onshore AF demagnetization of 162 large-volume samples from Holes 903A and 903C (Table 1) yielded much better results. In particular, we were able to derive a magnetostratigraphy for upper and middle Miocene silty clays, glauconitic silty clays, and glauconitic sands over the interval from 400 to 800 mbsf. From 400 to 535 mbsf, glauconitic sands and silty clays contained a magnetization stable to $\mathrm{AF}$ demagnetization to $50 \mathrm{mT}$ (Fig. 3A), suggesting a thick zone of normal polarity. We supplemented these data using a subset of reliable pass-through data between 400 and 485 mbsf in Hole 903A, which allowed a direct comparison of shipboard and shorebased results. Relative to the rest of the cores taken at this site, these upper Miocene sediments were left generally undisturbed by drilling and retained a relatively strong magnetization after $\mathrm{AF}$ cleaning to 15 $\mathrm{mT}(0.1-10 \mathrm{~mA} / \mathrm{m})$. By rechecking core photographs, we eliminated measurements taken in the vicinity of void spaces and at the edges of core sections. Inclination of remanence measured in our largevolume samples tended to average the broad scatter seen in the passthrough data (Fig. 4).

Below 485 mbsf in Hole 903A, magnetizations were generally weaker, particularly in intervals of greater sand content (Figs. 4, 5), and therefore we rely solely on shore-based results in these upper and middle Miocene sediments. The zone of normal-polarity magnetization continued down through the glauconitic sands and silty clays of lithostratigraphic Unit III to $535.21 \mathrm{mbsf}$, below the disconformity associated with Reflector m0.5. Note that the identification of Reflector m0.5 at Site 903 is uncertain: Mountain, Miller, Blum, et al. (1994) place it at 500 mbsf, but G.S. Mountain (pers. comm., 1995) places it at $520 \mathrm{mbsf}$ at the contact between lithostratigraphic Units III and IV. Below this disconformity, in gray silty clays, inclinations gradually inverted and remained reversed down to near the disconformity identified as Reflector m1 (604 mbsf; Mountain, Miller, Blum, et al., 1994). There were two short intervals of normal polarity within this zone: between 564.70 and 568.90 mbsf (defined by two samples) and between 579.82 and $588.10 \mathrm{mbsf}$ (defined by four samples). Sediments between about 605 and 630 mbsf were particularly high in sand content, making it difficult to isolate a stable magnetization. Below a zone of uncertain polarity at $630 \mathrm{mbsf}$ down to $756.6 \mathrm{mbsf}$ (in Hole $903 \mathrm{C}$ ), there was a thick zone of reversed-polarity magnetization relatively weak in intensity $(\sim 0.1 \mathrm{~mA} / \mathrm{m})$ but very stable to progressive AF demagnetization (Fig. 3B). Near the base of this zone

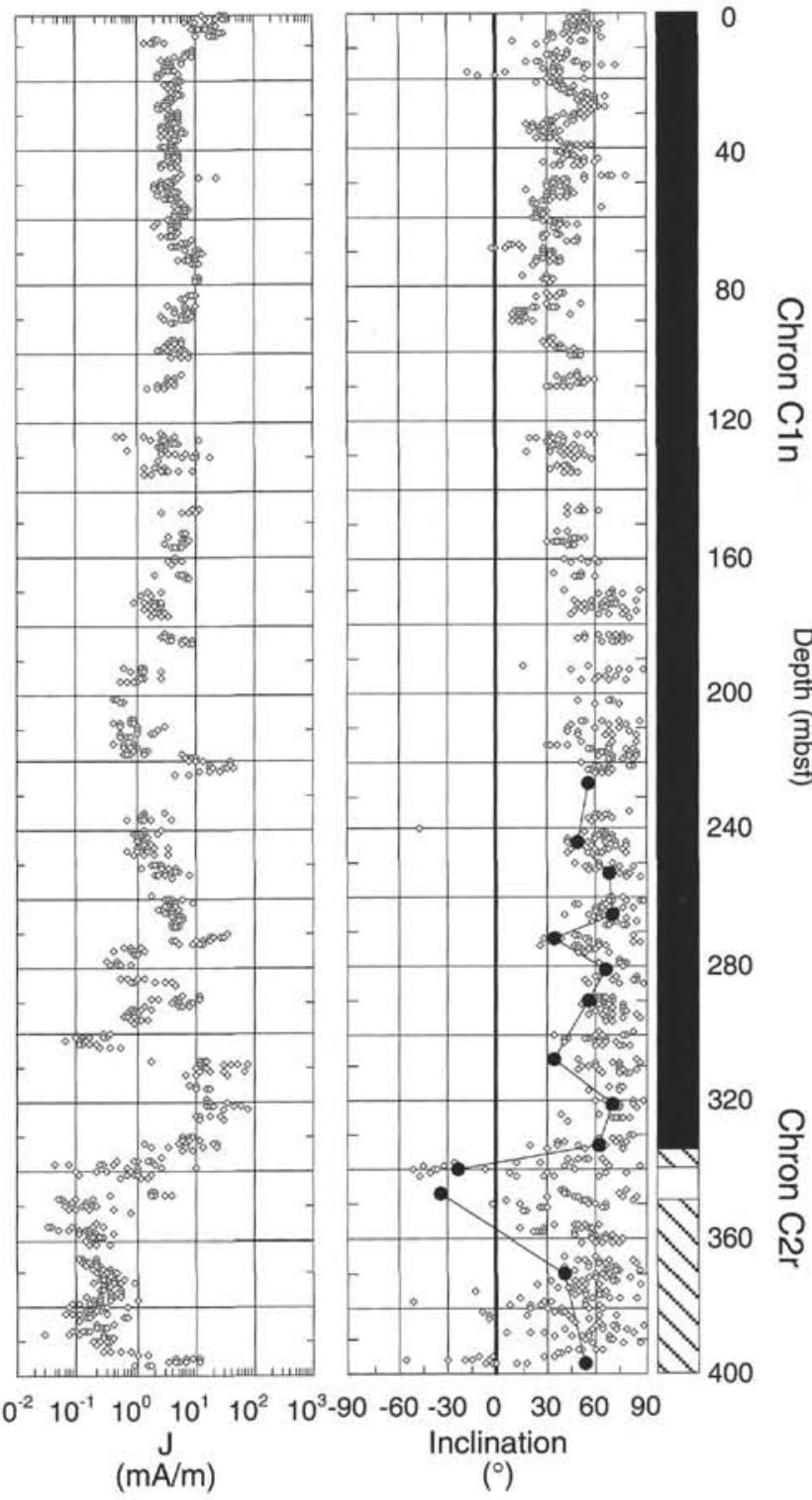

Figure 2. Inclination of remanence from Hole 903A, 0-400 mbsf, based on pass-through measurements (open diamonds) and 6- $\mathrm{cm}^{3}$ samples (solid circles). Polarity interpretation (black $=$ normal, white $=$ reverse) at right. Demagnetized intensity $(\mathrm{mA} / \mathrm{m})$ shown at left.

(718-756.6 mbsf), in organic-rich glauconitic silty clay, magnetizations gradually increased to $\sim 10 \mathrm{~mA} / \mathrm{m}$ on average (Fig. 5). Below a short section unsuitable for sampling, there was a normal-polarity zone (767.39-789.51 mbsf) followed by reversely magnetized sediments to 798.82 mbsf.

In summary, at Site 903 we have progressively AF demagnetized and analyzed 162 quarter-core samples, 18 of which were omitted from magnetostratigraphic analysis owing to weak and/or unstable magnetization. Based on the data from the remaining 144 samples, and selected portions of the pass-through data set, we incorporated the biostratigraphic data from Site 903 to make correlations to the GPTS (Table 2). The thick normal-polarity interval from seafloor to 332.56 is a partial record of Chron C1n (Brunhes Chron). SPECMAP identifications made aboard ship (Mountain, Miller, Blum, et al., 1994) suggest a correlation of the sediments at roughly $335 \mathrm{mbsf}$ to oxygen isotope Stage 15.1, and therefore the Pleistocene is truncated 
Table 1. Progressive demagnetization data from large-volume discrete samples used in constructing Site 903 magnetostratigraphy.

\begin{tabular}{|c|c|c|c|c|c|c|c|c|}
\hline $\begin{array}{l}\text { Core, section, } \\
\text { top }(\mathrm{cm})\end{array}$ & $\begin{array}{l}\text { Depth } \\
\text { (mbsf) }\end{array}$ & $N$ & $\begin{array}{l}\text { Var } \\
(\%)\end{array}$ & $\begin{array}{l}\text { Dec } \\
\left({ }^{\circ}\right)\end{array}$ & $\begin{array}{l}\text { Inc } \\
\left({ }^{\circ}\right)\end{array}$ & $\begin{array}{l}\text { First } \\
(\mathrm{mT})\end{array}$ & $\begin{array}{l}\text { Last } \\
(\mathrm{mT})\end{array}$ & $\begin{array}{c}\text { Jcomp } \\
(\mathrm{mA} / \mathrm{m})\end{array}$ \\
\hline $150-903 \mathrm{~A}-$ & & & & & & & & \\
\hline $37 X-3,138$ & 320.70 & 5 & 98.8 & 162.7 & 69.4 & 15.0 & 50.0 & 130.6595 \\
\hline $38 X-3,13$ & 329.86 & 5 & 99.3 & 288.7 & 73.6 & 15.0 & 50.0 & 3.2309 \\
\hline $41 X-4,15$ & 360.38 & 5 & 96.0 & 162.7 & 14.5 & 15.0 & 50.0 & 0.2831 \\
\hline $45 X-2,124$ & 397.07 & 4 & 94.3 & 29.9 & 23.3 & 15.0 & 40.0 & 0.1821 \\
\hline $46 X-3,14$ & 406.67 & 4 & 98.5 & 235.9 & 60.1 & 15.0 & 40.0 & 0.2369 \\
\hline $47 X-3,2$ & 416.75 & 5 & 95.8 & 184.4 & 44.6 & 15.0 & 50.0 & 0.8111 \\
\hline $48 X-5,87$ & 430.20 & 5 & 95.9 & 16.0 & 57.6 & 15.0 & 50.0 & 0.8657 \\
\hline $49 \mathrm{X}-3,11$ & 436.14 & 5 & 99.2 & 235.5 & 61.6 & 15.0 & 50.0 & 6.4792 \\
\hline $51 \times-3,29$ & 455.52 & 5 & 98.2 & 99.3 & 66.6 & 15.0 & 50.0 & 0.1154 \\
\hline $52 X-3,5$ & 464.98 & 5 & 99.8 & 180.1 & 54.0 & 15.0 & 50.0 & 24.5738 \\
\hline $53 \mathrm{X}-4,8$ & 476.21 & 5 & 98.2 & 332.4 & 38.0 & 15.0 & 49.0 & 0.2783 \\
\hline $54 X-4,19$ & 486.02 & 5 & 98.4 & 194.5 & 85.7 & 15.0 & 49.0 & 0.1066 \\
\hline $55 X-3,27$ & 494.20 & 5 & 87.5 & 207.8 & 68.2 & 15.0 & 49.0 & 0.0821 \\
\hline $55 X-5,127$ & 498.17 & 5 & 95.3 & 190.8 & 16.8 & 20.0 & 50.0 & 0.0352 \\
\hline $55 X-6,127$ & 499.67 & 5 & 66.2 & 101.5 & -59.9 & 20.0 & 50.0 & 0.0397 \\
\hline $56 \mathrm{X}-1,121$ & 501.81 & 5 & 97.2 & 186.5 & 43.3 & 20.0 & 50.0 & 0.1952 \\
\hline $56 X-4,96$ & 506.06 & 5 & 71.8 & 33.3 & 58.3 & 20.0 & 50.0 & 0.1252 \\
\hline $57 \times-1,19$ & 510.39 & 5 & 88.5 & 22.7 & 39.9 & 20.0 & 50.0 & 0.1147 \\
\hline $57 X-2,8$ & 511.81 & 5 & 96.1 & 307.7 & -21.3 & 15.0 & 49.0 & 0.5071 \\
\hline $57 X-4,53$ & 515.26 & 4 & 97.2 & 289.4 & 86.8 & 15.0 & 40.0 & 0.2757 \\
\hline $58 X-2,67$ & 522.10 & 5 & 96.5 & 301.7 & 62.9 & 15.0 & 49.0 & 0.0966 \\
\hline $58 X-4,15$ & 524.05 & 6 & 75.9 & 44.0 & 7.3 & 20.0 & 50.0 & 0.0902 \\
\hline $59 \mathrm{X}-1,55$ & 530.05 & 6 & 81.8 & 79.1 & 40.3 & 20.0 & 50.0 & 0.0369 \\
\hline $59 \times-3,23$ & 532.76 & 4 & 99.2 & 200.7 & 17.5 & 15.0 & 40.0 & 4.6497 \\
\hline $59 \mathrm{X}-3,90$ & 533.43 & 5 & 99.1 & 162.3 & -30.5 & 15.0 & 49.0 & 1.4576 \\
\hline $59 X-4,7$ & 534.07 & 6 & 93.1 & 153.5 & 31.9 & 20.0 & 50.0 & 0.9364 \\
\hline $59 \times-5,84$ & 536.34 & 5 & 95.7 & 106.5 & -40.0 & 20.0 & 50.0 & 0.4995 \\
\hline $60 X-1,2$ & 539.22 & 5 & 98.3 & 126.7 & -11.2 & 20.0 & 50.0 & 6.6388 \\
\hline $60 X-3,102$ & 543.25 & 4 & 98.3 & 219.8 & -25.1 & 20.0 & 49.0 & 3.7311 \\
\hline $61 X-2,17$ & 550.57 & 5 & 95.5 & 238.7 & -33.7 & 20.0 & 50.0 & 4.3319 \\
\hline $61 X-3,9$ & 552.02 & 4 & 91.7 & 177.8 & -34.6 & 20.0 & 49.0 & 4.6833 \\
\hline $61 X-4,86$ & 554.26 & 5 & 90.4 & 186.2 & -42.3 & 20.0 & 50.0 & 3.0535 \\
\hline $61 X-5,53$ & 555.43 & 5 & 84.4 & 22.8 & -69.0 & 20.0 & 50.0 & 2.8604 \\
\hline $61 X-6,113$ & 557.53 & 5 & 84.5 & 183.9 & -47.2 & 20.0 & 50.0 & 0.9742 \\
\hline $62 X-1,56$ & 559.06 & 5 & 98.5 & 242.9 & -27.0 & 20.0 & 50.0 & 6.9478 \\
\hline $62 X-2,17$ & 560.17 & 5 & 97.2 & 144.9 & -40.1 & 20.0 & 50.0 & 9.9176 \\
\hline $62 X-3,143$ & 562.96 & 5 & 99.4 & 104.5 & -47.0 & 15.0 & 49.0 & 6.8276 \\
\hline $62 X-4,30$ & 563.30 & 5 & 99.6 & 298.7 & -55.9 & 20.0 & 50.0 & 7.2242 \\
\hline $62 X-6,9$ & 566.09 & 5 & 95.0 & 248.6 & 27.8 & 20.0 & 50.0 & 0.0700 \\
\hline $63 \mathrm{X}-1,4$ & 567.84 & 7 & 74.7 & 181.9 & 37.2 & 20.0 & 48.0 & 0.0519 \\
\hline $63 X-2,64$ & 569.94 & 6 & 86.9 & 125.1 & -71.5 & 20.0 & 44.0 & 2.5892 \\
\hline $63 X-3,133$ & 572.16 & 5 & 98.8 & 66.7 & -35.6 & 15.0 & 49.0 & 0.3266 \\
\hline $63 X-4,60$ & 572.93 & 7 & 96.1 & 204.4 & -57.0 & 15.0 & 48.0 & 1.2573 \\
\hline $63 X-5,115$ & 574.98 & 3 & 77.0 & 189.9 & -40.1 & 42.0 & 48.0 & 5.0671 \\
\hline $63 \mathrm{X}-6,10$ & 575.43 & 3 & 97.8 & 178.0 & -39.0 & 40.0 & 48.0 & 10.8242 \\
\hline $64 X-1,79$ & 578.32 & 7 & 99.6 & 86.3 & -46.5 & 30.0 & 44.0 & 0.1921 \\
\hline $64 X-2,56$ & 579.59 & 6 & 69.6 & 36.2 & 23.0 & 15.0 & 40.0 & 0.1102 \\
\hline $64 X-3,78$ & 581.31 & 6 & 89.8 & 141.9 & 24.2 & 15.0 & 40.0 & 0.0995 \\
\hline $64 X-5,25$ & 583.78 & 5 & 99.2 & 210.0 & 68.8 & 15.0 & 49.0 & 0.1826 \\
\hline $64 X-6,33$ & 585.36 & 5 & 99.3 & 55.2 & 60.5 & 15.0 & 48.0 & 0.6266 \\
\hline $65 \mathrm{X}-1,22$ & 587.35 & 4 & 96.4 & 179.2 & 48.3 & 15.0 & 40.0 & 0.9514 \\
\hline $65 X-2,21$ & 588.84 & 5 & 98.6 & 84.0 & -78.5 & 15.0 & 48.0 & 9.6569 \\
\hline $65 X-3,4$ & 590.17 & 4 & 98.3 & 83.3 & -57.8 & 15.0 & 40.0 & 4.9526 \\
\hline $65 X-3,12$ & 590.25 & 5 & 98.8 & 0.0 & -54.1 & 15.0 & 49.0 & 5.4128 \\
\hline $65 X-4,84$ & 592.47 & 5 & 99.4 & 249.0 & -60.7 & 15.0 & 48,0 & 5.7709 \\
\hline $65 X-6,42$ & 595.05 & 5 & 94.0 & 219.7 & -33.4 & 15.0 & 50.0 & 12.8400 \\
\hline $67 X-2,67$ & 608.47 & 5 & 94.7 & 243.4 & 64.0 & 30.0 & 50.0 & 0.1621 \\
\hline $67 X-3,119$ & 610.52 & 5 & 68.1 & 45.9 & 35.6 & 15.0 & 49.0 & 0.0681 \\
\hline $67 X-5,34$ & 612.64 & 5 & 73.2 & 23.2 & -34.0 & 30.0 & 50.0 & 0.0642 \\
\hline $68 X-1,118$ & 617.18 & 5 & 92.5 & 224.8 & 30.9 & 30.0 & 50.0 & 0.0861 \\
\hline $68 \mathrm{X}-2,19$ & 617.69 & 5 & 75.1 & 339.7 & 49.0 & 20.0 & 50.0 & 0.0552 \\
\hline $68 \times-4,107$ & 621.57 & 5 & 66.9 & 185.9 & -54.0 & 20.0 & 50.0 & 0.0409 \\
\hline $68 X-5,91$ & 622.91 & 5 & 91.9 & 92.7 & 4.1 & 20.0 & 50.0 & 0.0569 \\
\hline $68 \times-6,135$ & 624.85 & 5 & 97.0 & 355.0 & -3.8 & 20.0 & 50.0 & 0.1269 \\
\hline $69 \mathrm{X}-2,124$ & 628.34 & 5 & 89.4 & 64.5 & -29.6 & 20.0 & 50.0 & 0.0507 \\
\hline $69 X-3,4$ & 628.67 & 4 & 89.6 & 292.6 & 48.3 & 15.0 & 40.0 & 0.0685 \\
\hline $69 X-4,100$ & 631.10 & 5 & 99.7 & 326.3 & -52.4 & 20.0 & 50.0 & 1.4107 \\
\hline $69 \times-5,124$ & 632.84 & 5 & 87.7 & 105.9 & -61.8 & 20.0 & 50.0 & 0.2133 \\
\hline $70 X-1,82$ & 636.02 & 5 & 97.2 & 130.2 & -17.9 & 20.0 & 50.0 & 0.0464 \\
\hline $70 X-2,41$ & 637.11 & 5 & 99.7 & 190.5 & 33.3 & 20.0 & 50.0 & 1.7331 \\
\hline $70 X-3,4$ & 638.27 & 5 & 99.4 & 26.8 & -63.4 & 15.0 & 49.0 & 0.6754 \\
\hline $71 X-1,0$ & 644.73 & 5 & 97.4 & 8.7 & -34.9 & 15.0 & 48.0 & 0.1085 \\
\hline $71 X-2,77$ & 647.00 & 5 & 99.1 & 15.5 & -52.1 & 15.0 & 48.0 & 0.1683 \\
\hline $71 X-3,119$ & 648.92 & 3 & 94.9 & 36.2 & -33.6 & 20.0 & 40.0 & 0.0588 \\
\hline $71 X-5,96$ & 651.69 & 3 & 98.5 & 72.7 & -35.8 & 20.0 & 40.0 & 0.0776 \\
\hline $71 X-6,90$ & 653.13 & 4 & 99.3 & 280.7 & -53.7 & 15.0 & 40.0 & 0.0850 \\
\hline $72 X-1,16$ & 654.59 & 4 & 98.7 & 13.3 & -27.8 & 15.0 & 40.0 & 0.0811 \\
\hline $72 \times-2,77$ & 656.70 & 4 & 98.6 & 116.5 & -25.4 & 15.0 & 40.0 & 0.0709 \\
\hline $72 X-3,123$ & 658.66 & 3 & 97.4 & 338.4 & 53.0 & 15.0 & 30.0 & 0.0150 \\
\hline $72 X-5,121$ & 661.64 & 4 & 92.1 & 209.5 & -28.8 & 15.0 & 40.0 & 0.0676 \\
\hline $73 X-1,30$ & 664.43 & 5 & 98.1 & 284.2 & -55.5 & 20.0 & 48.0 & 0.1142 \\
\hline $73 X-2,130$ & 666.93 & 5 & 89.8 & 282.9 & -18.6 & 15.0 & 44.0 & 0.0347 \\
\hline $73 X-3,60$ & 667.73 & 5 & 99.4 & 82.7 & -19.5 & 15.0 & 49.0 & 0.0897 \\
\hline $73 \times-4,138$ & 670.01 & 5 & 98.4 & 263.7 & -30.4 & 15.0 & 44.0 & 0.0719 \\
\hline $73 X-5,14$ & 670.27 & 5 & 96.7 & 36.2 & -4.1 & 20.0 & 48.0 & 0.0783 \\
\hline $73 \times-6,10$ & 671.73 & 5 & 98.7 & 284.8 & -43.1 & 20.0 & 48.0 & 0.1314 \\
\hline $74 X-1,33$ & 674.13 & 5 & 99.3 & 258.0 & 5.3 & 20.0 & 50.0 & 0.1054 \\
\hline $74 X-2,123$ & 676.53 & 5 & 99.0 & 148.4 & -32.1 & 20.0 & 50.0 & 0.1490 \\
\hline
\end{tabular}


Table 1 (continued).

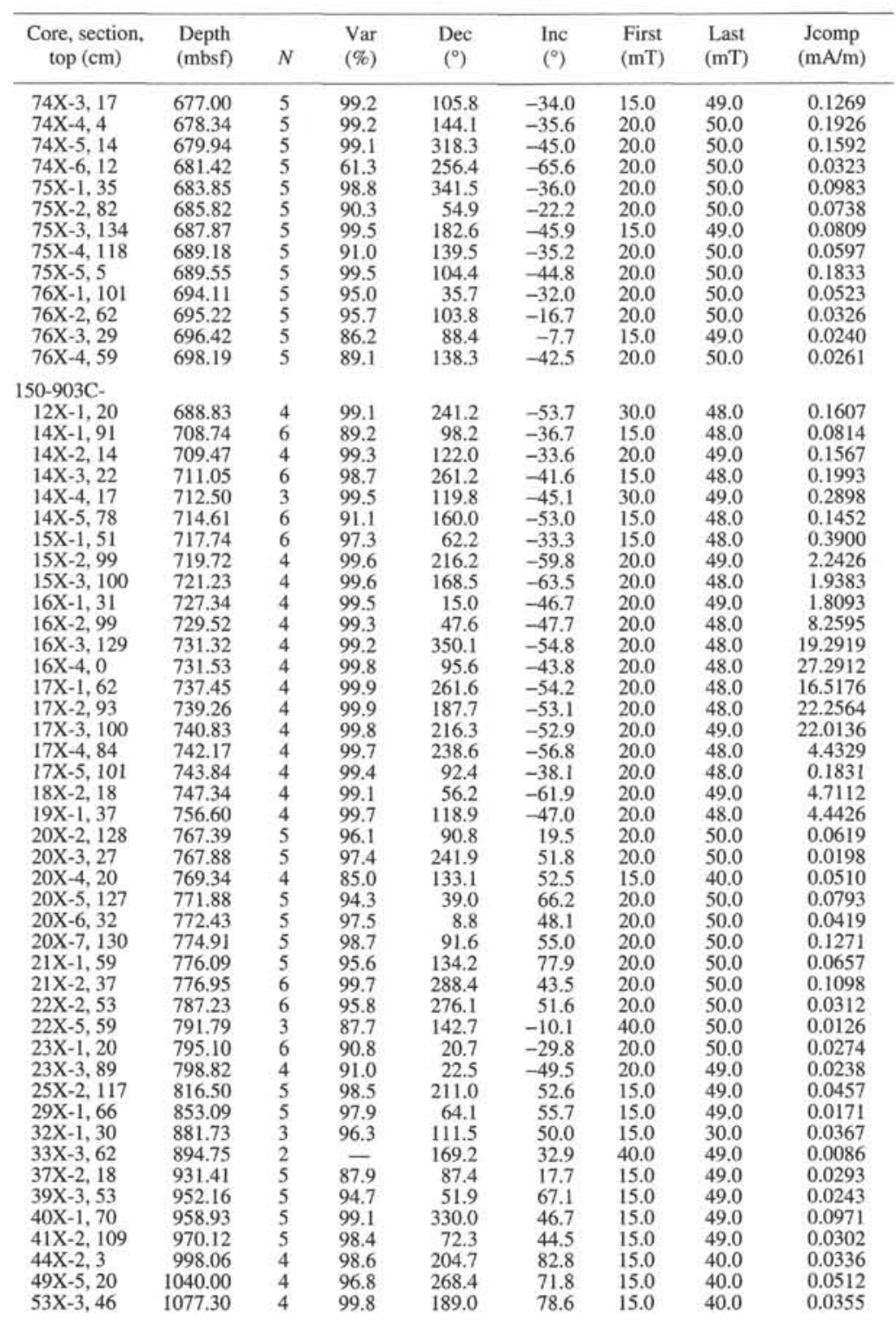

Notes: $N=$ number of data used in each least-squares analysis; Var = percentage of the total variance in the selected data accounted for by the least-squares vector (dash indicates variance calculation not applicable); Dec, Inc = declination and inclination of the magnetization vector; First, Last = first and last demagnetization step in millitesla; Jcomp = intensity of least-squares magnetization.

in Hole 903A within the zone of uncertain polarity between 332.56 and 340.07 mbsf (Fig. 2). The reversed-polarity interval (340.07$348.00 \mathrm{mbsf}$ ) is most likely a partial record of Chron $\mathrm{C} 2 \mathrm{r}$ given the middle or late Pliocene age of sediments at $352 \mathrm{mbsf}$ (Zones NN15 or NN17-18; Mountain, Miller, Blum, et al., 1994).

The highest occurrence of $D$. huestedi at $\sim 430$ mbsf is most likely a dissolution effect on the diatom record at Site 903 (Burckle, this volume). Nonetheless, this diatom suggests that the thick normalpolarity zone (400-535.21 mbsf) is correlative to Chron C5n (Table 2 ). The interval is truncated by a zone of ambiguous polarity above and the m 0.5 disconformity below, and therefore we can only identify the depth range of Chron $\mathrm{C} 5 \mathrm{n}$, not its onset or termination.

Based on the lowest occurrence of Denticulopsis punctata var. hustedii at 540 mbsf (Burckle, this volume), we correlate the generally reversed-polarity zone between 535.21 and $601 \mathrm{mbsf}$ to Chron C5r. In the equatorial Pacific, the last appearance of this diatom has a direct tie to the magnetostratigraphic record (Burckle et al., 1982). Chron C5r at Site 903 is unfortunately truncated by disconformities, but the two well-defined normal-polarity intervals within this zone may allow us to offer a more precise correlation to the GPTS (Chrons C5r.1n and C5r.2n; Table 2).

Snyder et al. (this volume) offer a planktonic foraminiferal zonation (N11-N12) for the sediments below Reflector m1 (604 mbsf) to a depth of about $760 \mathrm{mbsf}$ in Holes $903 \mathrm{~A}$ and $903 \mathrm{C}$. The boundary between dinoflagellate cyst Zones E and F (Zones DN6 and DN7 of deVerteuil, this volume) has been identified at 799.6 mbsf in Hole 903C (Mountain, Miller, Blum, et al., 1994). These sediments are therefore middle Miocene. Given these data and our correlations of the sediments above Reflector $\mathrm{m} 1$, we suggest the reversed interval between $630 \mathrm{mbsf}$ and $756.6 \mathrm{mbsf}$ is correlative to Chron C5Ar, with the thin normal-polarity zone between 767.39 and $789.51 \mathrm{mbsf}$ representing either Chron C5Ar.1n or Chron C5Ar.2n. We note, how- 
A
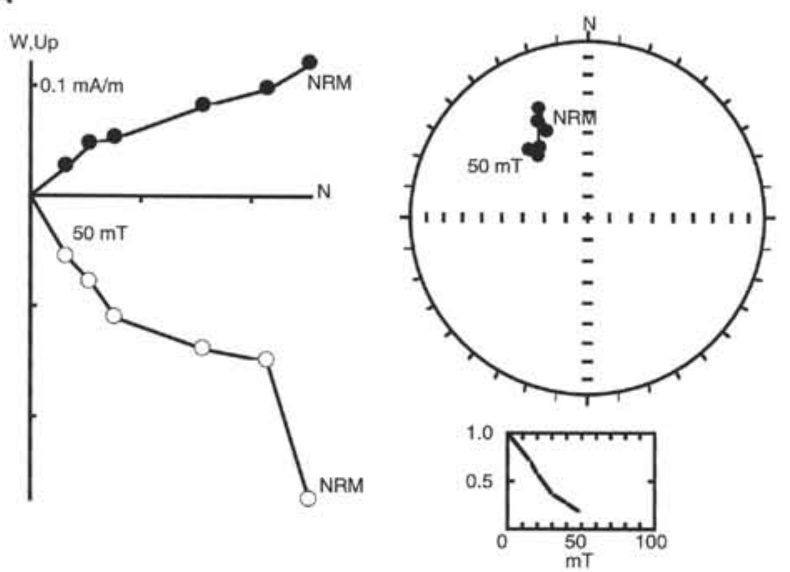

B
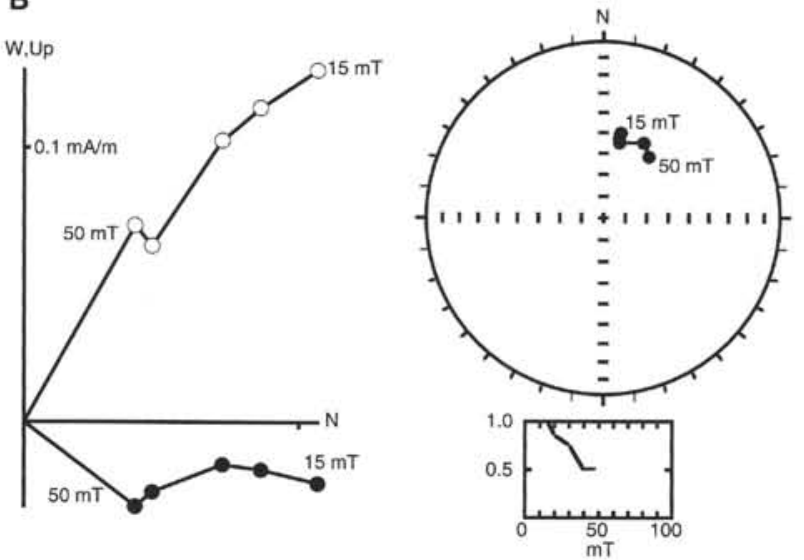

Figure 3. Progressive AF demagnetization of large-volume samples from Hole 903A. A. 150-903A-53X-4, $8 \mathrm{~cm}$ (depth $476.21 \mathrm{mbsf}$, volume $42 \mathrm{~cm}^{3}$ ). B. 150-903A-71X-2, $77 \mathrm{~cm}$ (depth $647.00 \mathrm{mbsf}$, volume $42 \mathrm{~cm}^{3}$ ). For each sample, orthographic projection is shown at left (solid/open symbols $=$ horizontal/vertical projection, $\mathrm{mT}=$ millitesla). Equal-area projections of same data shown at right along with normalized magnetization intensity (lower right)

ever, that the biostratigraphic data below Reflector $\mathrm{ml}$ lack the necessary age precision to rule out a correlation of these sediments to Chron C5r.

\section{Site 904}

Site 904 is located at $38^{\circ} 52^{\prime} \mathrm{N}, 72^{\circ} 46^{\prime} \mathrm{W}$ on the lower slope in $1123 \mathrm{~m}$ of water. We recovered middle and upper Eocene clayey chalk, upper Oligocene through upper Miocene silty clay, glauconitic silty clay and sand, and middle to upper Pleistocene silty clay in a 577 -m section.

Like the other Leg 150 sites, most of the section recovered at Site 904 was weakly magnetized. The intensity of natural and demagnetized remanence was relatively strong in the upper $140 \mathrm{~m}$ (one to several tens of $\mathrm{mA} / \mathrm{m}$ ) but became notably weak from this level to the bottom of the hole (on the order of $0.1 \mathrm{~mA} / \mathrm{m} ;$ Fig. 6). In addition, we suspected the 15-mT limit in $\mathrm{AF}$ demagnetization was not enough to remove overprints in the pre-Pleistocene sediments. Demagnetized remanence from the pass-through data yielded a uniform zone of normal polarity in the upper $99 \mathrm{~m}$ of homogenous silty clays and fine sands. Inclination of the stable magnetization revealed in six largevolume samples from this interval confirmed the pass-through results. As in the case of Site 903, data from the large-volume discrete samples tended to average the overall scatter of inclination measured aboard ship (Fig. 6; Table 3).

Below a disconformity at $\sim 105$ mbsf down to 130 mbsf magnetizations from upper Miocene bioturbated silty clays yielded a well-defined stable magnetization (Fig. 7). Compared to the rather shallow inclinations measured with the pass-through system, more thorough demagnetization in the large-volume samples revealed a steeper and very consistent reversed-polarity magnetization (inclinations $=-50^{\circ}$ to $-60^{\circ}$; Fig. 6). This was probably an effect of our ability to more completely remove steep normal-polarity overprints in discrete samples.

For the remainder of Hole $904 \mathrm{~A}$, we rely solely on data from large-volume discrete samples. Magnetization intensities were consistently on the order of $0.1 \mathrm{~mA} / \mathrm{m}$ from depths of $130 \mathrm{mbsf}$ to about $180 \mathrm{mbsf}$ (the depth of disconformity identified as Reflector $\mathrm{m1}$; Mountain, Miller, Blum, et al., 1994; Fig. 6). Polarity reversals were more common in the upper Miocene silty clays and overall, inclinations were rather inconsistent, in the range of $\pm 20^{\circ}-70^{\circ}$. AF demagnetization revealed a stable magnetization (Fig. 7) defining a thick, predominantly reversed-polarity zone between 168.71 and 225.64 mbsf. In the lower half of this interval, intensities gradually increased to $>1 \mathrm{~mA} / \mathrm{m}$ (Figs. 6,8). This zone was interrupted by a few short polarity zones based on relatively shallow inclinations between 185.16 and 198.98 mbsf (Fig. 6).

Below about 225 mbsf in Hole 904A, magnetization intensities were relatively weak $(\sim 0.1 \mathrm{~mA} / \mathrm{m})$ but stable to progressive $\mathrm{AF}$ demagnetization (Fig. 8). Considering these low intensities, inclination remained remarkably consistent $\left( \pm 30^{\circ}-60^{\circ}\right)$ through the interval with the exception of two samples at $\sim 306$ mbsf and two at $\sim 379$ mbsf (Fig. 8). In these lower Miocene and upper Oligocene sediments, polarity was predominantly normal marked by a few relatively short reverse intervals. A zone of glauconitic sand between 275 and $290 \mathrm{mbsf}$ was not suitable for paleomagnetic sampling. Below about $340 \mathrm{mbsf}$, magnetizations in glauconitic silty clays and silts began to approach even our estimated lower limit on measurement using the large-volume sample method $(0.01 \mathrm{~mA} / \mathrm{m}$; Fig. 8 ; Table 3$)$.

In summary, at Site 904 we have progressively AF demagnetized and analyzed 166 quarter-core samples. There were no omissions at this site, although the weak magnetizations in samples below 350 mbsf should be judged with caution. Along with selected portions of the pass-through data set, the biostratigraphic and Sr-isotopic data allow us to correlate portions of the magnetostratigraphy of Site 904 to the GPTS (Table 2; Fig. 9). The normal-polarity interval from the seafloor to $99 \mathrm{mbsf}$ is correlated to Chron C1n. Based on the shipboard nannofossil zonations from this site (Mountain, Miller, Blum, et al., 1994), the Brunhes Chron is truncated in the upper part of Zone NN19 (middle Pleistocene).

The section between the disconformities associated with seismic Reflectors $\mathrm{m} 0.7$ and $\mathrm{m} 1$ ( $~ 105$ to $180.30 \mathrm{mbsf})$ contains a fairly welldefined reversal sequence. Lacking any diagnostic fossils or Srisotope data in this interval, we venture to correlate these sediments to the GPTS on the basis of a reversal pattern fit and certain boundary conditions (Table 2). The sediments immediately underneath Disconformity $\mathrm{m} 1$ at 180.30 are correlated to Chron C $5 \mathrm{r}$ (discussed below), and therefore the section above must be younger than middle Miocene. Furthermore, we do not see evidence for the relatively long period of normal polarity in this interval (Chron C5n, nearly 1.4 m.y. in duration; Berggren et al., 1985). Therefore the section between 105 and 180.30 mbsf must be younger than middle Miocene, and is probably younger than Chron C $5 n$. Given these general observations and assuming a constant sedimentation rate, we propose a correlation of this section to the middle late Miocene portion of the GPTS from Chron C4r.1r (partim) to Chron 4Ar.2r (partim). On the basis of the identification of C4r. In (termination) at 109.49 mbsf and C4Ar.1n (onset) at $168.71 \mathrm{mbsf}$, we calculate an average sedimentation rate of $51 \mathrm{~m} / \mathrm{m}$.y. Naturally, we could have correlated to any part of the GPTS between the Pleistocene and middle late Miocene; however, 

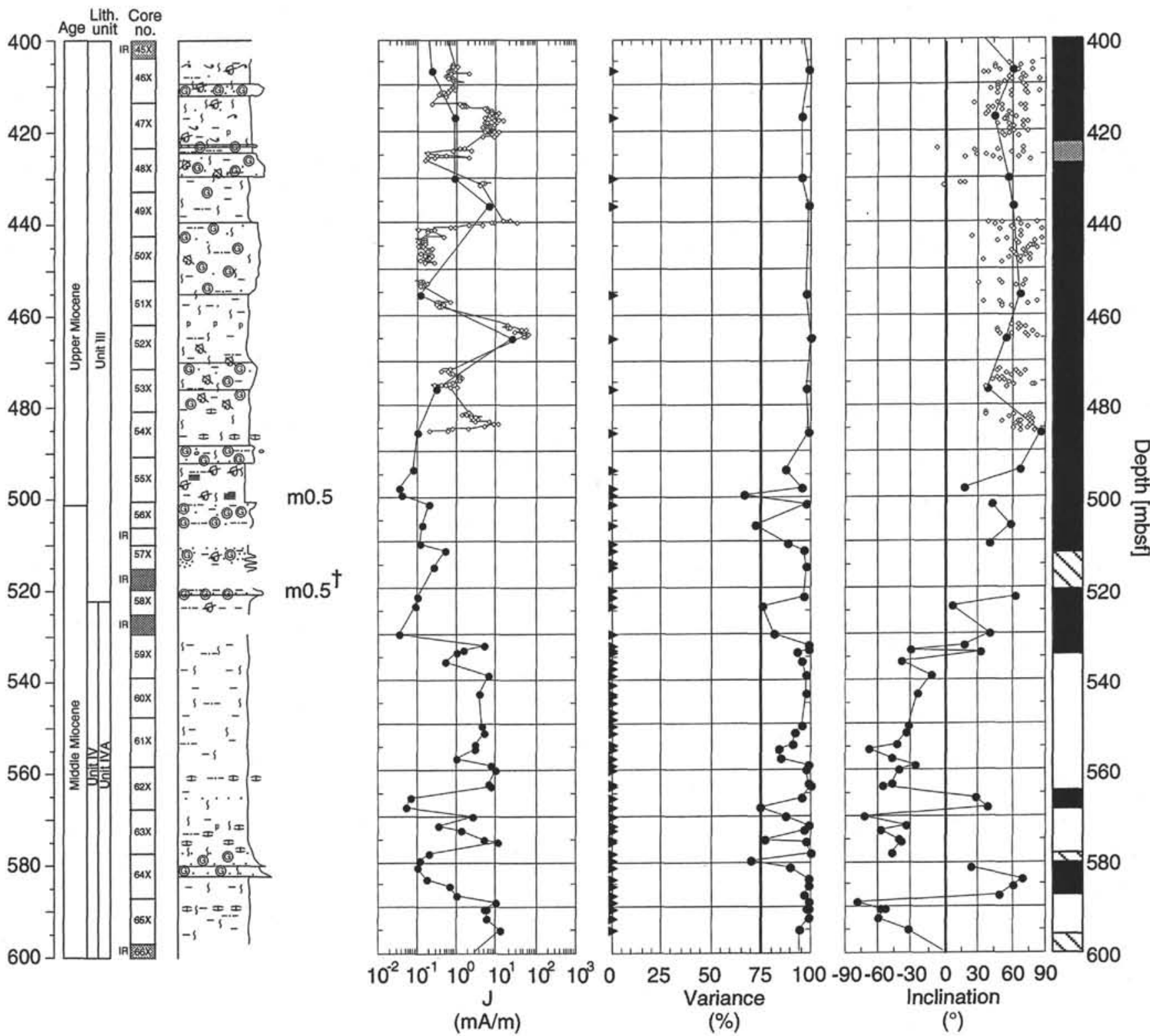

Figure 4. Inclination of remanence from Hole 903A, 400-600 mbsf, based on pass-through measurements (open diamonds) and large-volume discrete samples (solid circles), with polarity zonation shown at right. Magnetization intensity $(\mathrm{mA} / \mathrm{m})$ and percent-variance shown in center (triangles give location of discrete samples). Lithologic column and seismic reflectors (Mountain, Miller, Blum, et al., 1994) shown at left. G.S. Mountain (pers. comm., 1995) places Reflector $\mathrm{m} 0.5(\mathrm{~m} 0.5 \div)$ at $520 \mathrm{mbsf}$.

planktonic foraminifers in Core 150-904A-19H suggest an assignment to Zone N17 (Snyder, this volume). Nannofossils from the same core suggest a correlation to Zone NN10 (Aubry, in Mountain, Miller, Blum, et al., 1994), and therefore the sediments immediately above Disconformity $\mathrm{ml}$ are most likely upper Miocene.

Between Disconformities m1 (180.30 mbsf) and m2 (220 mbsf), we use the middle Miocene planktonic foraminifer zonations from Snyder (this volume) to correlate to the GPTS (Table 2). Zone N13 identified at the top of this interval suggests that the reversed zone between 180 and 185.16 mbsf represents Chron C5r. The highest occurrence of Globorotalia fohsi robusta at about $184 \mathrm{mbsf}$ and lowest occurrence of Globorotalia fohsi fohsi at about 190 mbsf suggest Chron C5An between 185.16 and 198.98 mbsf based on Berggren et al. (1985). Unfortunately, the magnetizations that define Chron C5An. $1 \mathrm{n}$ have low inclination, and C5An.2n is tentatively defined by one sample (Fig. 6). Deeper in Hole 904A, Sr isotope data are avail- able to aid correlation (Miller, Liu, and Feigenson, this volume). The thick reversed-polarity zone from 198.98 to $225.64 \mathrm{mbsf}$ is correlated to Chron C5Ar (Table 2; Fig. 9) on the basis of $\mathrm{Sr}$ isotope data down to 210 mbsf. We note that the lowest occurrence of Globorotalia peripheroacuta at about 197 mbsf suggests an assignment to the top of Zone N11 (i.e., slightly older than the onset of Chron C5Ar), although this lowest occurrence may be delayed due to relatively poor preservation at these depths (Snyder, this volume).

Continuing down through the remainder of the middle Miocene at Site 904 , average $\mathrm{Sr}$ isotope age dates of $12.9 \pm 1.4$ m.y. and $16.3 \pm$ 1.4 m.y. (Miller, Liu, and Feigenson, this volume) suggest assignment of the polarity zones between 225.64 and 243.09 mbsf to Chron C5AA and between 243.09 to 251.90 mbsf to Chron C5Br (Table 2). A gap of about $2 \mathrm{~m} . \mathrm{y}$. in the $\mathrm{Sr}$ isotope age data at $243 \mathrm{mbsf}$ implies a major hiatus in the section. Below $252 \mathrm{mbsf}$, the dating of lower Miocene and upper Oligocene sediments at Site 904 is controlled en- 

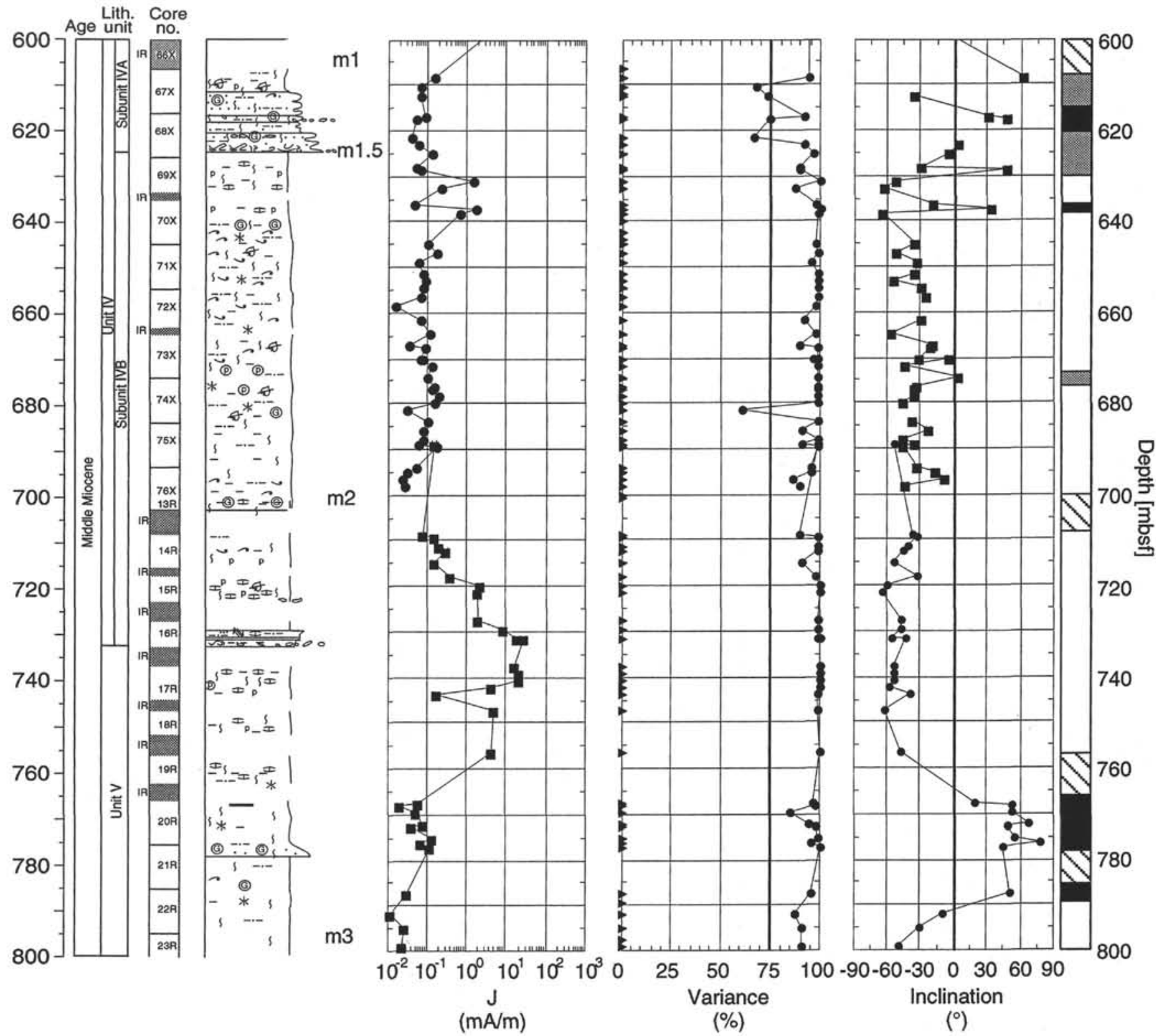

Figure 5. Inclination of remanence from Holes $903 \mathrm{~A}$ and $903 \mathrm{C}, 600-800 \mathrm{mbsf}$, based on large-volume discrete samples (solid symbols), with polarity zonation shown at right. Magnetization intensity $(\mathrm{mA} / \mathrm{m})$ and percent-variance shown in center (triangles give location of discrete samples). Lithologic column and seismic reflectors (Mountain, Miller, Blum, et al., 1994) shown at left.

tirely by $\mathrm{Sr}$ isotope data and planktonic foraminifer zonations. Our magnetostratigraphy (Fig. 9) for this part of the section is presented as a working framework for future work. Within the resolution of $\mathrm{Sr}$ isotope dating, this part of the section may have undergone continuous sedimentation (Miller, Liu, and Feigenson, this volume) terminating in Chron C5Cn between 251.90 and 259.00 mbsf. The concurrence of ranges of Globorotalia praescitula and Globorotalia miozea at these depths supports this assignment in the late early Miocene (Snyder, this volume).

\section{DISCUSSION}

Magnetostratigraphy in the near-shore paleoenvironment has been successful in recently published studies (Miller et al., 1990; 1993) and current studies of cores from the New Jersey Coastal Plain (Leg 150X). A key advantage of studying ocean and coastal plain boreholes is that we can avoid problems related to weathering in outcrops (e.g., Ellwood et al., 1986). In this study, by increasing the sample size over the standard ODP paleomagnetic sample, we were able to amplify the signal at the magnetometer and sample perhaps a more representative population of inefficiently or complexly magnetized grains. Although we lose the relative ease and efficiency of the passthrough method of measuring cores, sampling by way of the largevolume discrete sample has enabled more thorough $\mathrm{AF}$ demagnetization and increased sensitivity to weakly magnetized sediments, the data from which might have otherwise been overlooked.

Given the relatively steep depositional surfaces on the upper slope $\left(>1.6^{\circ}\right.$; Heezen et al., 1959$)$ and the vulnerability to canyon incisement in this setting, we do not necessarily anticipate sedimentary sequences bounded by seafloor seismic reflectors to correlate between sites. We might expect more continuity of sequences between proximal drill sites as we move up to shallower $\left(<0.6^{\circ}\right)$ depositional surfaces of the continental shelf. An example of this may be seen in com- 
Table 2. Polarity zonations and reversal boundary depths for Sites $\mathbf{9 0 3}$ and 904.

\begin{tabular}{|c|c|c|c|}
\hline Depth & Sense & Interpretation & Age \\
\hline \multicolumn{4}{|l|}{ Site 903} \\
\hline $0.00-332.56$ & $\mathrm{~N}$ & $\mathrm{C} 1 \mathrm{n}$ & Pleistocene \\
\hline $340.07-348.00$ & $\mathrm{R}$ & $\mathrm{C} 2 \mathrm{r}$ & middle late Pliocene \\
\hline $400.00-535.21$ & $\mathrm{~N}$ & C5n (partim) & early late Miocene \\
\hline $535.21-601.76$ & $\mathbf{R}$ & C5r (partim) & late middle Miocene \\
\hline 564.70 & $\mathrm{~N}-\mathrm{R}$ & C5r. $\ln (\mathrm{T})$ & 10.54 \\
\hline 568.90 & $\mathrm{R}-\mathrm{N}$ & $\mathrm{C} 5 \mathrm{r} \cdot \ln (\mathrm{O})$ & 10.59 \\
\hline 579.82 & $\mathrm{~N}-\mathrm{R}$ & C $5 \mathrm{r} .2 \mathrm{n}(\mathrm{T})$ & 11.03 \\
\hline 588.10 & $\mathrm{R}-\mathrm{N}$ & $\mathrm{C} 5 \mathrm{r} .2 \mathrm{n}(\mathrm{O})$ & 11.09 \\
\hline $630.00-756.60$ & $\mathrm{R}$ & C5r (partim) & late middle Miocene \\
\hline \multicolumn{4}{|l|}{ Site 904} \\
\hline $0.00-99.00$ & $\mathrm{~N}$ & $\mathrm{Cln}$ & Pleistocene \\
\hline 109.49 & $\mathrm{~N}-\mathrm{R}$ & $\mathrm{C} 4 \mathrm{r} \cdot \ln (\mathrm{T})$ & 7.35 \\
\hline 112.34 & $\mathrm{R}-\mathrm{N}$ & $\mathrm{C} 4 \mathrm{r} \cdot \ln (\mathrm{O})$ & 7.41 \\
\hline 129.53 & $\mathrm{~N}-\mathrm{R}$ & $\mathrm{C} 4 \mathrm{An}(\mathrm{T})$ & 7.90 \\
\hline 147.30 & $\mathrm{R}-\mathrm{N}$ & $\mathrm{C} 4 \mathrm{An}(\mathrm{O})$ & 8.21 \\
\hline 162.46 & $\mathrm{~N}-\mathrm{R}$ & $\mathrm{C} 4 \mathrm{Ar} \cdot \ln (\mathrm{T})$ & 8.41 \\
\hline 168.71 & $\mathrm{R}-\mathrm{N}$ & $\mathrm{C} 4 \mathrm{Ar} \cdot \ln (\mathrm{O})$ & 8.50 \\
\hline 198.98 & $\mathrm{R}-\mathrm{N}$ & $\mathrm{C} 5 \mathrm{An}(\mathrm{O})$ & 12.12 \\
\hline
\end{tabular}

Notes: Ages from Berggren et al. (1985); chronostratigraphic notation from Cande and Kent (1992); $\mathrm{O}=$ onset, $\mathrm{T}=$ termination, $\mathrm{N}=$ normal, $\mathrm{R}=$ reverse.

paring the sedimentary sections between common disconformities at Sites 903 (upper slope) and 904 (lower slope). At Site 903, the section between Reflectors $\mathrm{m} 0.5$ and $\mathrm{ml}$ was correlated to Chron C5r (Fig. 9). Note that in seismic profiles on the New Jersey Margin (G. Mountain, K. Miller, and N. Christie-Blick, unpubl. data, 1990), Reflector $\mathrm{m} 0.7$ pinches out to $\mathrm{m} 0.5$ moving upslope to the position of Site 903. Downslope at Site 904, the sediments bounded by Disconformities $\mathrm{m} 0.7$ and $\mathrm{ml}$ were correlated to the GPTS from Chron C4r.1r (partim) to Chron 4Ar.2r (partim). Thus, both packages of sediments span roughly a million years but differ in age by about 3 million years (i.e., become younger) moving off the shelf. This may suggest that Reflector $\mathrm{ml}$ represents a downlap surface and that sediments were deposited out onto the slope as sea level fell during the first half of the late Miocene.

\section{ACKNOWLEDGMENTS}

We are indebted to Mimi Katz for her hours of assistance in the shore-based sampling of Leg 150 cores and to Paula Weiss for guid- ing us through the sampling regimen. Gilberto Mello made most of the paleomagnetic measurements at the LDEO laboratory. We also thank Monica Sweitzer, our technician on the JOIDES Resolution, for helping us with the pass-through measurements and data crunching. This study was supported by JOI/USSAC.

\section{REFERENCES}

Berggren, W.A., Kent, D.V., Flynn, J.J., and Van Couvering, J.A., 1985. Cenozoic geochronology. Geol. Soc. Am. Bull., 96:1407-1418.

Burckle, L.H., Keigwin, L.D., and Opdyke, N.D., 1982. Middle and late Miocene stable isotope stratigraphy: correlation to the paleomagnetic reversal record. Micropaleontology, 28:329-334.

Cande, S.C., and Kent, D.V., 1992. A new geomagnetic polarity time scale for the Late Cretaceous and Cenozoic. J. Geophys. Res., 97:1391713951.

Christie-Blick, N..,Mountain, G.S., and Miller, K.G., 1990. Stratigraphic and seismic stratigraphic record of sea-level change. In Sea-level Change: Washington (National Academy Press), 116-140.

Ellwood, B.B., McPherson, J.G., Sen Gupta, B.K., and Matthews, M., 1986. The proposed Eocene-Oligocene stratotype, S.W. Alabama: not ideal due to magnetostratigraphic inconsistencies. Palaios, 1:417-419.

Greenlee, S.M., Devlin, W.J., Miller, K.G., Mountain, G.S., and Flemings, P.B., 1992. Integrated sequence stratigraphy of Neogene deposits, New Jersey continental shelf and slope: comparison with the Exxon model. Geol. Soc. Am. Bull., 104:1403-1411.

Heezen, B.C., Tharp, M., and Ewing, M., 1959. The floors of the Ocean, 1. The North Atlantic. Spec. Pap.-Geol. Soc. Am., 65.

Kirschvink, J.L., 1980. The least-squares line and plane and the analysis of palaeomagnetic data. Geophys. J. R. Astron. Soc., 62:699-718.

Miller, K.G., Kent, D.V., Brower, A.N., Bybell, L.M., Feigenson, M.D., Olsson, R.K., and Poore, R.Z., 1990. Eocene-Oligocene sea-level changes on the New Jersey coastal plain linked to the deep-sea record. Geol. Soc. Am. Bull., 102:331-339.

Miller, K.G., Thompson, P.R., and Kent, D.V., 1993. Integrated late EoceneOligocene stratigraphy of the Alabama coastal plain: correlation of hiatuses and stratal surfaces to glacioeustatic lowerings. Paleoceanography, 8:313-331.

Mountain, G.S., Miller, K.G., Blum, P., et al., 1994. Proc. ODP, Init. Repts. 150: College Station, TX (Ocean Drilling Program).

Date of initial receipt: 6 March 1995

Date of acceptance: 26 September 1995 Ms 150SR-010 

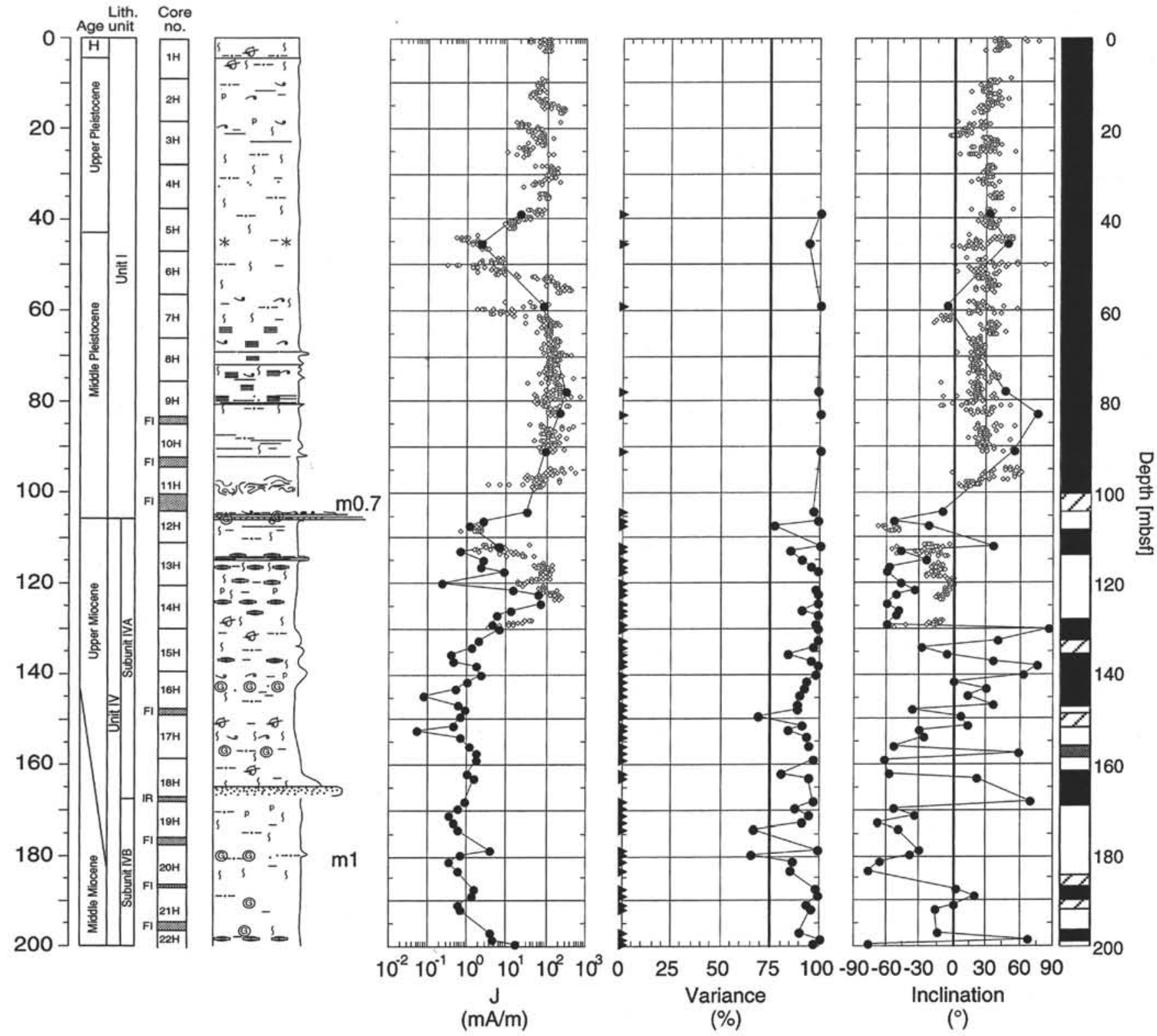

Figure 6. Inclination of remanence from Hole 904A, 0-200 mbsf, based on pass-through measurements (open diamonds) and large-volume discrete samples (solid symbols), with polarity zonation shown at right. Magnetization intensity $(\mathrm{mA} / \mathrm{m})$ and percent-variance shown in center (triangles give location of discrete samples). Lithologic column and seismic reflectors (Mountain, Miller, Blum, et al., 1994) shown at left. 
Table 3. Progressive demagnetization data from large-volume discrete samples used in constructing Site 904 magnetostratigraphy.

\begin{tabular}{|c|c|c|c|c|c|c|c|c|}
\hline $\begin{array}{l}\text { Core, section, } \\
\text { top }(\mathrm{cm})\end{array}$ & $\begin{array}{l}\text { Depth } \\
\text { (mbsf) }\end{array}$ & $N$ & $\begin{array}{l}\text { Var } \\
(\%)\end{array}$ & $\begin{array}{c}\text { Dec } \\
\left({ }^{\circ}\right)\end{array}$ & $\begin{array}{l}\text { Inc } \\
\left({ }^{\circ}\right)\end{array}$ & $\begin{array}{l}\text { First } \\
(\mathrm{mT})\end{array}$ & $\begin{array}{l}\text { Last } \\
(\mathrm{mT})\end{array}$ & $\begin{array}{l}\text { Jcomp } \\
(\mathrm{mA} / \mathrm{m})\end{array}$ \\
\hline 150-904A- & & & & & & & & \\
\hline $5 \mathrm{H}-2,90$ & 38.93 & 4 & 99.9 & 137.1 & 31.1 & 15.0 & 50.0 & 2.1940 \\
\hline $5 \mathrm{H}-6,55$ & 45.58 & 4 & 94.0 & 172.0 & 49.4 & 15.0 & 50.0 & 0.2135 \\
\hline $7 \mathrm{H}-2,90$ & 58.93 & 4 & 99.6 & 206.9 & -5.1 & 15.0 & 50.0 & 7.9542 \\
\hline $9 \mathrm{H}-2,94$ & 77.97 & 4 & 99.5 & 27.7 & 46.3 & 15.0 & 50.0 & 29.9669 \\
\hline $9 \mathrm{H}-6,4$ & 83.07 & 4 & 99.6 & 62.2 & 75.9 & 15.0 & 50.0 & 21.1690 \\
\hline $10 \mathrm{H}-4,125$ & 90.78 & 5 & 99.8 & 37.8 & 55.4 & 15.0 & 50.0 & 9.0904 \\
\hline $12 \mathrm{H}-1,5$ & 104.08 & 5 & 96.7 & 40.8 & -9.7 & 15.0 & 40.0 & 3.1588 \\
\hline $12 \mathrm{H}-2,92$ & 106.45 & 5 & 98.8 & 325.9 & -52.8 & 15.0 & 48.0 & 0.2678 \\
\hline $12 \mathrm{H}-3,5$ & 107.05 & 5 & 76.6 & 291.5 & -22.0 & 15.0 & 40.0 & 0.1188 \\
\hline $13 \mathrm{H}-1,90$ & 111.93 & 5 & 99.7 & 85.0 & 36.6 & 15.0 & 48.0 & 0.6661 \\
\hline $13 \mathrm{H}-2,22$ & 112.75 & 5 & 84.7 & 317.2 & -48.0 & 15.0 & 50.0 & 0.0678 \\
\hline $13 \mathrm{H}-3,90$ & 114.93 & 5 & 91.0 & 61.1 & -23.7 & 15.0 & 48.0 & 0.2673 \\
\hline $13 \mathrm{H}-4,67$ & 116.20 & 5 & 95.1 & 310.5 & -58.1 & 15.0 & 48.0 & 0.2250 \\
\hline $13 \mathrm{H}-5,22$ & 117.25 & 5 & 98.7 & 283.9 & -60.8 & 15.0 & 50.0 & 0.8457 \\
\hline $13 \mathrm{H}-6,120$ & 119.73 & 2 & - & 30.8 & -48.0 & 40.0 & 48.0 & 0.0233 \\
\hline $14 \mathrm{H}-1,90$ & 121.43 & 5 & 98.1 & 36.5 & -35.6 & 15.0 & 48.0 & 1.3509 \\
\hline $14 \mathrm{H}-2,45$ & 122.48 & 5 & 99.0 & 61.0 & -52.1 & 15.0 & 50.0 & 6.5481 \\
\hline $14 \mathrm{H}-3,90$ & 124.43 & 5 & 99.0 & 56.0 & -58.9 & 15.0 & 48.0 & 6.6326 \\
\hline $14 \mathrm{H}-4,100$ & 126.03 & 5 & 90.8 & 43.6 & -48.9 & 15.0 & 48.0 & 1.3073 \\
\hline $14 \mathrm{H}-5,45$ & 126.98 & 5 & 98.4 & 51.0 & -51.9 & 15.0 & 50.0 & 0.5766 \\
\hline $14 \mathrm{H}-6,90$ & 128.93 & 5 & 97.3 & 30.0 & -59.9 & 15.0 & 48.0 & 0.4516 \\
\hline $15 \mathrm{H}-1,10$ & 130.13 & 5 & 98.4 & 234.0 & 86.3 & 15.0 & 48.0 & 0.6145 \\
\hline $15 \mathrm{H}-2,90$ & 132.43 & 5 & 98.8 & 311.6 & 40.7 & 15.0 & 50.0 & 0.1850 \\
\hline $15 \mathrm{H}-3,96$ & 133.99 & 5 & 96.5 & 28.1 & -28.8 & 15.0 & 48.0 & 0.1295 \\
\hline $15 \mathrm{H}-4,50$ & 135.53 & 5 & 84.0 & 320.1 & -6.6 & 15.0 & 48.0 & 0.0381 \\
\hline $15 \mathrm{H}-5,90$ & 136.93 & 4 & 96.0 & 87.7 & 35.5 & 15.0 & 40.0 & 0.0466 \\
\hline $15 \mathrm{H}-6,85$ & 138.38 & 5 & 99.2 & 129.1 & 76.4 & 15.0 & 49.0 & 0.1788 \\
\hline $16 \mathrm{H}-1,85$ & 140.38 & 5 & 98.0 & 307.9 & 62.0 & 15.0 & 49.0 & 0.2288 \\
\hline $16 \mathrm{H}-2,90$ & 141.93 & 4 & 93.7 & 90.5 & 1.0 & 15.0 & 40.0 & 0.1042 \\
\hline $16 \mathrm{H}-3,90$ & 143.43 & 5 & 91.8 & 56.2 & 29.8 & 15.0 & 49.0 & 0.0500 \\
\hline $16 \mathrm{H}-4,51$ & 144.54 & 5 & 89.3 & 276.8 & 12.7 & 15.0 & 49.0 & 0.0083 \\
\hline $16 \mathrm{H}-5,103$ & 146.56 & 5 & 88.6 & 221.1 & 37.1 & 15.0 & 50.0 & 0.0581 \\
\hline $16 \mathrm{H}-6,100$ & 148.03 & 5 & 88.5 & 59.2 & -36.8 & 15.0 & 49.0 & 0.0883 \\
\hline $17 \mathrm{H}-1,30$ & 149.33 & 5 & 68.9 & 343.2 & 6.6 & 15.0 & 49.0 & 0.0621 \\
\hline $17 \mathrm{H}-2,90$ & 151.43 & 5 & 90.9 & 142.4 & 12.2 & 15.0 & 50.0 & 0.0473 \\
\hline $17 \mathrm{H}-3,20$ & 152.23 & 4 & 84.4 & 129.4 & -30.9 & 15.0 & 40.0 & 0.0052 \\
\hline $17 \mathrm{H}-4,15$ & 153.68 & 4 & 92.7 & 316.0 & -26.9 & 15.0 & 40.0 & 0.0633 \\
\hline $17 \mathrm{H}-5,90$ & 155.93 & 5 & 93.9 & 302.9 & -52.8 & 15.0 & 50.0 & 0.1202 \\
\hline $17 \mathrm{H}-6,85$ & 157.38 & 2 & - & 88.9 & 58.8 & 49.0 & 49.0 & 0.1611 \\
\hline $18 \mathrm{H}-1,20$ & 158.73 & 5 & 97.1 & 356.1 & -61.8 & 15.0 & 49.0 & 0.1681 \\
\hline $18 \mathrm{H}-3,25$ & 161.78 & 5 & 80.7 & 310.9 & -58.4 & 15.0 & 49.0 & 0.1002 \\
\hline $18 \mathrm{H}-4,10$ & 163.13 & 5 & 94.3 & 71.5 & 21.5 & 15.0 & 49.0 & 0.1440 \\
\hline $19 \mathrm{H}-1,25$ & 168.28 & 5 & 96.2 & 357.9 & 68.7 & 15.0 & 48.0 & 0.0904 \\
\hline $19 \mathrm{H}-2,18$ & 169.71 & 5 & 87.2 & 349.3 & -53.9 & 15.0 & 50.0 & 0.0564 \\
\hline $19 \mathrm{H}-3,30$ & 171.33 & 5 & 94.5 & 269.1 & -35.9 & 15.0 & 48.0 & 0.0357 \\
\hline $19 \mathrm{H}-4,15$ & 172.68 & 5 & 90.6 & 244.2 & -68.1 & 15.0 & 48.0 & 0.0435 \\
\hline $19 \mathrm{H}-5,18$ & 174.21 & 5 & 66.9 & 222.9 & -48.9 & 15.0 & 50.0 & 0.0602 \\
\hline $20 \mathrm{H}-1,115$ & 178.68 & 5 & 98.9 & 309.0 & -30.1 & 15.0 & 48.0 & 0.3933 \\
\hline $20 \mathrm{H}-2,90$ & 179.93 & 5 & 65.8 & 287.2 & -39.4 & 15.0 & 48.0 & 0.0652 \\
\hline $20 \mathrm{H}-3,95$ & 181.48 & 5 & 85.7 & 225.6 & -65.2 & 15.0 & 50.0 & 0.0361 \\
\hline $20 \mathrm{H}-4,100$ & 183.03 & 4 & 85.4 & 318.0 & -76.2 & 20.0 & 48.0 & 0.0611 \\
\hline $21 \mathrm{H}-1,25$ & 187.28 & 5 & 97.6 & 2.0 & 1.9 & 15.0 & 48.0 & 0.1566 \\
\hline $21 \mathrm{H}-2,50$ & 189.03 & 5 & 99.0 & 323.4 & 19.0 & 15.0 & 48.0 & 0.1285 \\
\hline $21 \mathrm{H}-3,95$ & 190.98 & 5 & 93.6 & 11.6 & 1.2 & 15.0 & 50.0 & 0.0571 \\
\hline $21 \mathrm{H}-4,25$ & 191.78 & 5 & 95.8 & 30.5 & -17.1 & 15.0 & 48.0 & 0.0678 \\
\hline $22 \mathrm{H}-1,25$ & 196.78 & 5 & 89.2 & 21.6 & -14.4 & 15.0 & 48.0 & 0.3623 \\
\hline $22 \mathrm{H}-2,20$ & 198.23 & 4 & 99.6 & 256.5 & 68.2 & 15.0 & 48.0 & 0.4183 \\
\hline $22 \mathrm{H}-3,19$ & 199.72 & 5 & 97.0 & 28.9 & -76.8 & 15.0 & 50.0 & 1.6892 \\
\hline $22 \mathrm{H}-4,16$ & 201.19 & 5 & 99.3 & 350.0 & -46.1 & 15.0 & 48.0 & 3.2602 \\
\hline $23 \mathrm{H}-1,120$ & 204.23 & 5 & 98.3 & 29.4 & -27.6 & 15.0 & 48.0 & 0.4054 \\
\hline $23 \mathrm{H}-2,18$ & 204.71 & 5 & 98.6 & 36.4 & -33.2 & 15.0 & 50.0 & 0.9366 \\
\hline $23 \mathrm{H}-3,20$ & 206.23 & 5 & 98.9 & 25.7 & -21.1 & 15.0 & 48.0 & 1.8545 \\
\hline $23 \mathrm{H}-4,120$ & 208.73 & 5 & 99.8 & 32.1 & -22.0 & 15.0 & 50.0 & 1.0426 \\
\hline $23 \mathrm{H}-5,20$ & 209.23 & 6 & 99.3 & 30.2 & -38.7 & 15.0 & 48.0 & 0.9852 \\
\hline $24 \mathrm{X}-1,120$ & 213.73 & 5 & 99.6 & 5.1 & -40.3 & 15.0 & 48.0 & 0.3007 \\
\hline $24 \mathrm{X}-2,82$ & 214.85 & 5 & 97.5 & 38.8 & -52.4 & 15.0 & 50.0 & 0.1816 \\
\hline $24 \mathrm{X}-3,29$ & 215.82 & 5 & 98.7 & 14.2 & -48.4 & 15.0 & 48.0 & 0.5495 \\
\hline $24 X-4,120$ & 218.23 & 5 & 99.9 & 20.7 & -49.2 & 15.0 & 48.0 & 18.4788 \\
\hline $24 X-5,35$ & 218.88 & 5 & 99.9 & 19.9 & -55.8 & 15.0 & 50.0 & 31.2666 \\
\hline $25 \mathrm{X}-1,125$ & 223.28 & 5 & 96.1 & 339.5 & -47.9 & 15.0 & 48.0 & 0.0319 \\
\hline $25 X-2,135$ & 224.88 & 5 & 99.9 & 256.5 & -65.2 & 15.0 & 48.0 & 0.8154 \\
\hline $25 X-3,136$ & 226.39 & 5 & 99.5 & 67.3 & 50.1 & 15.0 & 48.0 & 0.7281 \\
\hline $25 X-4,25$ & 226.78 & 5 & 86.5 & 267.6 & 29.0 & 15.0 & 48.0 & 0.0381 \\
\hline $25 X-5,120$ & 229.23 & 5 & 99.7 & 261.7 & 27.1 & 15.0 & 50.0 & 1.6228 \\
\hline $25 X-6,12$ & 229.65 & 5 & 97.4 & 189.4 & 46.9 & 15.0 & 48.0 & 0.0890 \\
\hline $26 X-3,20$ & 234.53 & 3 & 96.5 & 152.8 & 46.7 & 15.0 & 30.0 & 0.0231 \\
\hline $26 \times-4,81$ & 236.64 & 5 & 82.5 & 5.0 & 24.2 & 15.0 & 48.0 & 0.0276 \\
\hline $26 \times-5,16$ & 237.49 & 5 & 98.7 & 9.8 & -26.1 & 15.0 & 48.0 & 0.3740 \\
\hline $26 \mathrm{X}-6,81$ & 239.64 & 5 & 94.5 & 126.5 & 81.7 & 15.0 & 48.0 & 0.0795 \\
\hline $27 \mathrm{X}-1,101$ & 241.94 & 5 & 99.1 & 124.2 & -0.2 & 15.0 & 48.0 & 0.0419 \\
\hline $27 \mathrm{X}-2,94$ & 243.37 & 5 & 82.2 & 152.6 & -69.5 & 15.0 & 48.0 & 0.0431 \\
\hline $27 \mathrm{X}-3,122$ & 245.15 & 5 & 97.3 & 7.9 & -81.4 & 15.0 & 50.0 & 0.0566 \\
\hline $27 \mathrm{X}-4,21$ & 245.64 & 5 & 73.6 & 274.1 & 20.4 & 15.0 & 48.0 & 0.0088 \\
\hline $27 \mathrm{X}-5,28$ & 247.21 & 5 & 98.2 & 36.6 & 4.5 & 15.0 & 48.0 & 0.1454 \\
\hline $28 \mathrm{X}-1,84$ & 251.17 & 5 & 89.5 & 183.2 & -27.8 & 15.0 & 48.0 & 0.0119 \\
\hline $28 X-2,79$ & 252.62 & 5 & 94.7 & 57.3 & 41.7 & 15.0 & 48.0 & 0.0395 \\
\hline $28 \mathrm{X}-3,48$ & 253.81 & 5 & 83.0 & 119.4 & 63.5 & 15.0 & 48.0 & 0.0378 \\
\hline $28 \mathrm{X}-5,18$ & 256.61 & 5 & 83.2 & 169.6 & 66.4 & 15.0 & 48.0 & 0.0190 \\
\hline
\end{tabular}


Table 3 (continued).

\begin{tabular}{|c|c|c|c|c|c|c|c|c|}
\hline $\begin{array}{c}\text { Core, section, } \\
\text { top }(\mathrm{cm})\end{array}$ & $\begin{array}{l}\text { Depth } \\
\text { (mbsf) }\end{array}$ & $N$ & $\begin{array}{l}\text { Var } \\
(\%)\end{array}$ & $\begin{array}{l}\text { Dec } \\
\left({ }^{\circ}\right)\end{array}$ & $\begin{array}{l}\text { Inc } \\
\left({ }^{\circ}\right)\end{array}$ & $\begin{array}{l}\text { First } \\
(\mathrm{mT})\end{array}$ & $\begin{array}{l}\text { Last } \\
(\mathrm{mT})\end{array}$ & $\begin{array}{c}\text { Jcomp } \\
(\mathrm{mA} / \mathrm{m})\end{array}$ \\
\hline $29 \mathrm{X}-1,120$ & 261.33 & 5 & 99.6 & 153.9 & 59.3 & 15.0 & 48.0 & 0.5883 \\
\hline $29 \times-2,65$ & 262.28 & 5 & 98.8 & 330.6 & 47.1 & 15.0 & 50.0 & 12.8276 \\
\hline $30 \times-2,125$ & 272.58 & 2 & - & 243.8 & 57.7 & 40.0 & 50.0 & 0.0652 \\
\hline $32 X-2,131$ & 291.94 & 5 & 98.6 & 153.9 & 25.9 & 15.0 & 50.0 & 0.6121 \\
\hline $32 \times-3,137$ & 293.50 & 5 & 99.6 & 282.5 & 19.7 & 15.0 & 48.0 & 0.6409 \\
\hline $32 X-5,93$ & 296.06 & 5 & 99.2 & 276.8 & 62.7 & 15.0 & 50.0 & 0.9378 \\
\hline $32 X-6,18$ & 296.81 & 5 & 98.5 & 211.4 & 48.5 & 15.0 & 48.0 & 0.0466 \\
\hline $33 \mathrm{X}-1,118$ & 300.01 & 5 & 99.6 & 254.1 & -30.2 & 15.0 & 48.0 & 1.3469 \\
\hline $33 X-2,144$ & 301.77 & 3 & 92.4 & 179.2 & -65.7 & 15.0 & 30.0 & 0.0259 \\
\hline $33 X-3,135$ & 303.18 & 5 & 98.6 & 121.6 & -43.2 & 15.0 & 48.0 & 0.1778 \\
\hline $33 \times-4,25$ & 303.58 & 5 & 94.6 & 196.8 & 58.4 & 15.0 & 48.0 & 0.0316 \\
\hline $33 \times-5,25$ & 305.08 & 5 & 96.2 & 96.2 & 19.1 & 15.0 & 50.0 & 0.0633 \\
\hline $33 \times-6,131$ & 307.64 & 5 & 91.6 & 343.8 & -9.0 & 15.0 & 48.0 & 0.0273 \\
\hline $34 \mathrm{X}-1,99$ & 309.42 & 3 & 96.7 & 278.2 & 38.7 & 40.0 & 48.0 & 0.0131 \\
\hline $34 X-2,10$ & 310.03 & 5 & 99.9 & 129.5 & -70.0 & 15.0 & 50.0 & 2.0888 \\
\hline $34 X-3,9$ & 311.52 & 6 & 97.4 & 107.7 & -29.8 & 15.0 & 48.0 & 1.3019 \\
\hline $34 X-4,25$ & 313.18 & 4 & 91.7 & 265.5 & -17.4 & 30.0 & 48.0 & 0.1052 \\
\hline $34 X-5,91$ & 315.34 & 5 & 99.1 & 172.6 & 54.4 & 15.0 & 50.0 & 0.1778 \\
\hline $34 X-6,45$ & 316.38 & 2 & - & 326.6 & -28.9 & 48.0 & 49.0 & 0.0350 \\
\hline $35 \times-4,124$ & 323.57 & 6 & 92.3 & 238.0 & -38.9 & 20.0 & 49.0 & 0.0664 \\
\hline $35 X-5,20$ & 324.03 & 5 & 98.7 & 160.8 & 33.1 & 15.0 & 50.0 & 1.3423 \\
\hline $36 \mathrm{X}-2,142$ & 330.15 & 5 & 98.1 & 74.7 & 69.6 & 15.0 & 50.0 & 0.1985 \\
\hline $36 \times-5,65$ & 333.88 & 5 & 97.7 & 106.3 & 24.5 & 15.0 & 50.0 & 0.0533 \\
\hline $37 X-1,126$ & 337.79 & 6 & 97.3 & 70.6 & 31.4 & 20.0 & 49.0 & 0.0447 \\
\hline $37 X-2,46$ & 338.49 & 5 & 98.0 & 332.3 & 23.8 & 30.0 & 49.0 & 0.0245 \\
\hline $37 X-3,75$ & 340.28 & 2 & - & 212.3 & -68.3 & 40.0 & 50.0 & 0.0385 \\
\hline $37 X-4,88$ & 341.91 & 4 & 97.2 & 25.2 & 38.0 & 30.0 & 48.0 & 0.0104 \\
\hline $37 X-6,52$ & 344.55 & 5 & 87.2 & 335.3 & 24.7 & 20.0 & 48.0 & 0.0271 \\
\hline $38 \mathrm{X}-2,133$ & 348.66 & 4 & 99.8 & 168.5 & 65.7 & 15.0 & 40.0 & 0.5316 \\
\hline $38 X-5,19$ & 352.02 & 4 & 95.6 & 206.7 & 67.1 & 15.0 & 40.0 & 0.0123 \\
\hline $39 X-2,53$ & 357.56 & 5 & 75.8 & 219.3 & 8.8 & 15.0 & 50.0 & 0.0278 \\
\hline $39 \times-5,76$ & 362.29 & 5 & 86.8 & 17.5 & 74.3 & 15.0 & 50.0 & 0.0109 \\
\hline $40 \times-2,127$ & 367.90 & 5 & 94.9 & 132.4 & 71.8 & 15.0 & 50.0 & 0.0228 \\
\hline $40 X-5,118$ & 372.31 & 5 & 91.1 & 240.8 & 62.9 & 15.0 & 50.0 & 0.0133 \\
\hline $40 \times-6,53$ & 373.16 & 3 & 98.3 & 54.2 & 29.5 & 30.0 & 44.0 & 0.0097 \\
\hline $41 X-1,123$ & 376.06 & 5 & 93.6 & 270.6 & -37.5 & 15.0 & 50.0 & 0.0357 \\
\hline $41 X-2,75$ & 377.08 & 2 & - & 119.2 & -21.2 & 40.0 & 50.0 & 0.0066 \\
\hline $41 X-3,104$ & 378.87 & 3 & 97.1 & 13.6 & 8.6 & 30.0 & 44.0 & 0.0083 \\
\hline $41 X-4,13$ & 379.46 & 3 & 96.2 & 208.2 & 13.0 & 30.0 & 44.0 & 0.0052 \\
\hline $41 X-5,57$ & 381.40 & 5 & 88.2 & 266.0 & 71.0 & 15.0 & 50.0 & 0.0250 \\
\hline $41 X-6,5$ & 382.38 & 3 & 93.3 & 164.2 & -30.3 & 20.0 & 40.0 & 0.0207 \\
\hline $42 X-2,5$ & 385.98 & 5 & 89.5 & 166.4 & 67.4 & 15.0 & 50.0 & 0.0109 \\
\hline $42 X-5,60$ & 391.03 & 5 & 86.4 & 338.0 & 45.5 & 15.0 & 50.0 & 0.0195 \\
\hline $42 \times-6,137$ & 393.30 & 4 & 99.1 & 332.2 & -62.6 & 30.0 & 48.0 & 0.0133 \\
\hline $43 \times-1,136$ & 395.49 & 3 & 87.0 & 227.3 & -63.0 & 15.0 & 30.0 & 0.0085 \\
\hline $43 X-2,84$ & 396.47 & 5 & 90.5 & 29.4 & 37.8 & 15.0 & 48.0 & 0.0116 \\
\hline $43 \times-3,47$ & 397.60 & 5 & 87.9 & 38.6 & -54.3 & 15.0 & 50.0 & 0.0083 \\
\hline $43 X-4,105$ & 399.68 & 5 & 71.5 & 104.9 & -2.9 & 15.0 & 48.0 & 0.0042 \\
\hline
\end{tabular}

Notes: $N=$ number of data used in each least-squares analysis; Var = percentage of the total variance in the selected data accounted for by the least-squares vector (dash indicates variance calculation not applicable); Dec, Inc = declination and inclination of the magnetization vector; First, Last = first and last demagnetization step in millitesla; Jcomp = intensity of least-squares magnetization. 
A

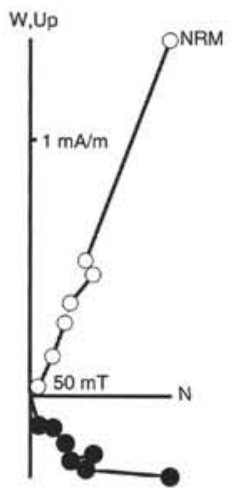

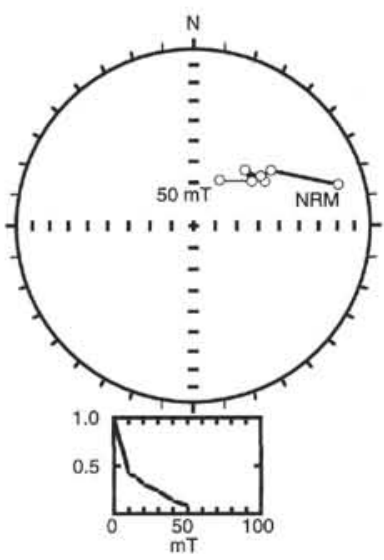

B

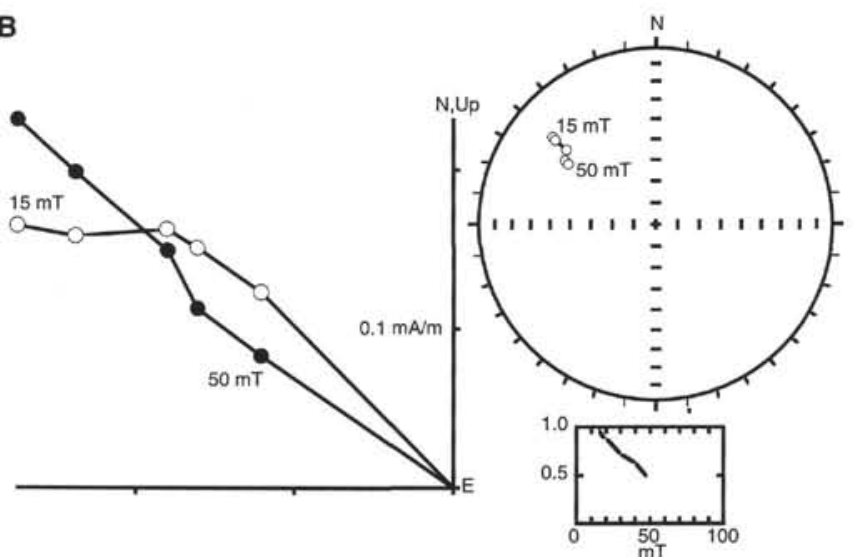

Figure 7. Progressive AF demagnetization of large-volume samples from Hole $904 \mathrm{~A}$. A. $150-904 \mathrm{~A}-14 \mathrm{H}-5,45 \mathrm{~cm}$ (depth $126.98 \mathrm{mbsf}$, volume $42 \mathrm{~cm}{ }^{3}$ ). B. 150 904A-20H-1, $115 \mathrm{~cm}$ (depth $178.68 \mathrm{mbsf}$, volume $42 \mathrm{~cm}^{3}$ ). For each sample, orthographic projection is shown at left (solid/open symbols = horizontal/vertical projection, $\mathrm{mT}=$ millitesla). Equal-area projections of same data shown at right along with normalized magnetization intensity (lower right). 


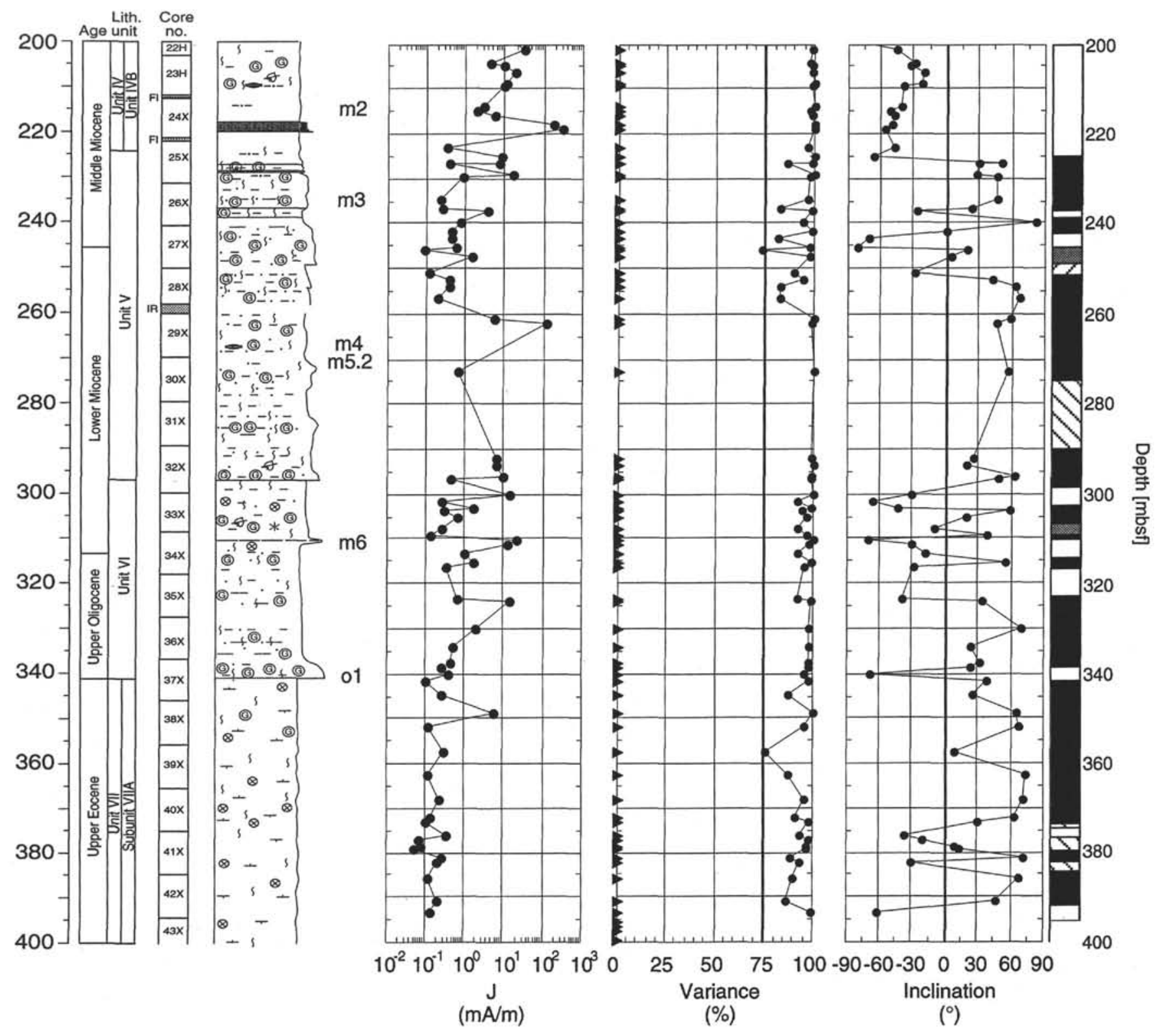

Figure 8. Inclination of remanence from Hole 904A, 200-400 mbsf, based on large-volume discrete samples (solid symbols), with polarity zonation shown at right. Magnetization intensity $(\mathrm{mA} / \mathrm{m})$ and percent-variance shown in center (triangles give location of discrete samples). Lithologic column and seismic reflectors (Mountain, Miller, Blum, et al., 1994) shown at left. 
Site 903

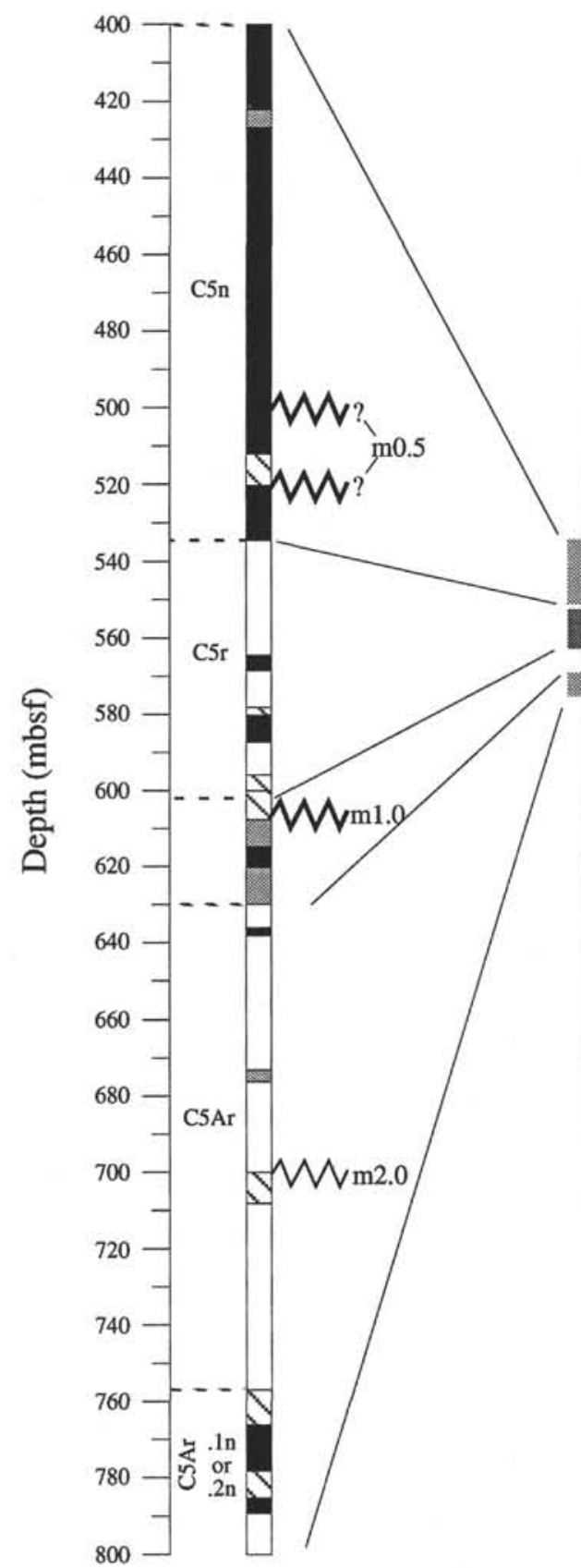

Site 904

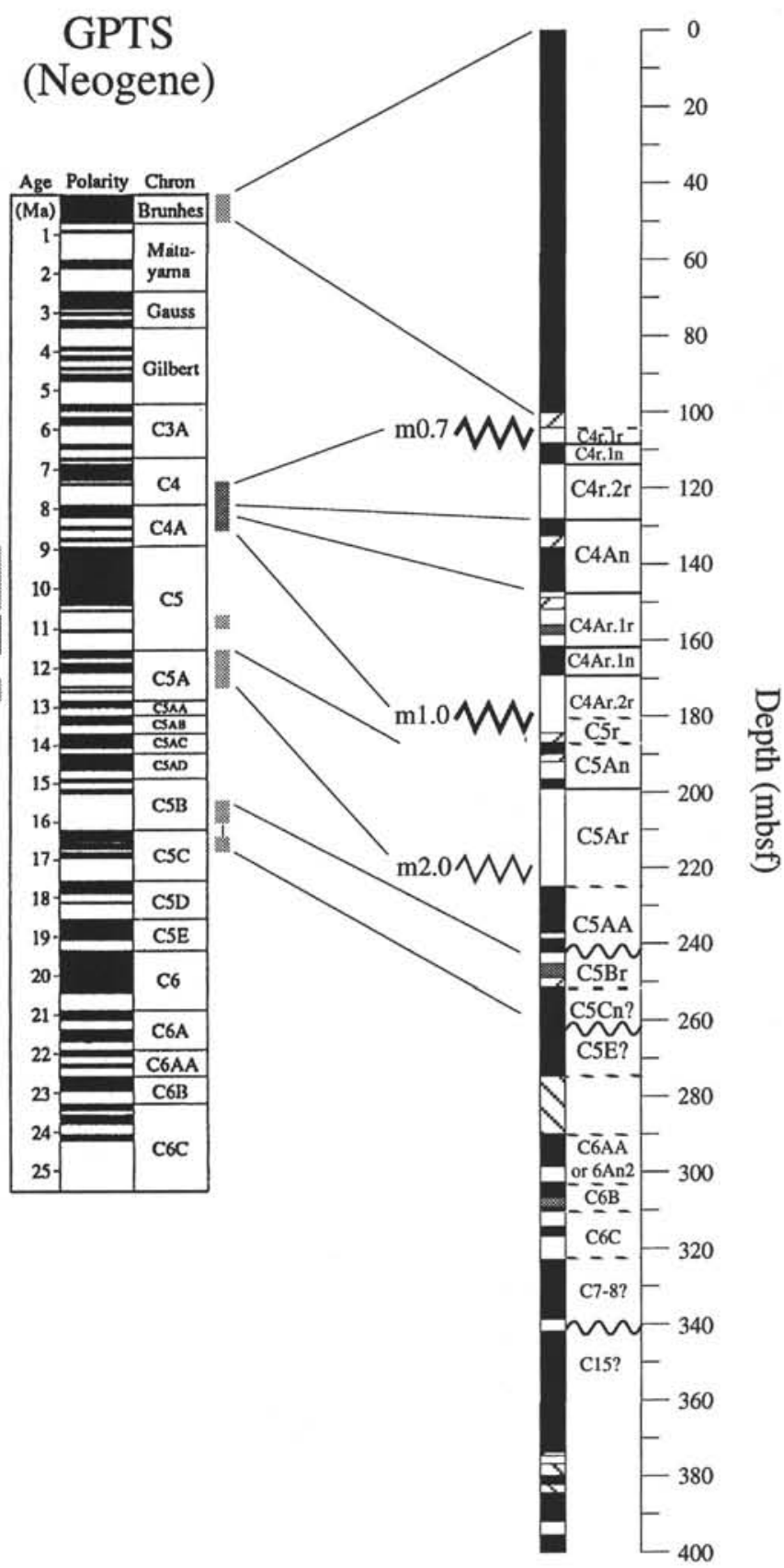

Figure 9. Correlation of Site 903 (400-800 mbsf) and Site 904 (0-400 mbsf) magnetostratigraphy to the Neogene geomagnetic polarity time scale (Berggren et al., 1985). Black zones = normal polarity, white zones = reverse polarity. Gray zones indicate a reversal based on only one sample; therefore, polarity is uncertain. Hatched zones show where no polarity determination was possible. Prominent disconformities associated with seafloor seismic reflectors shown by jagged lines. 